Western University

Scholarship@Western

Civil and Environmental Engineering

Civil and Environmental Engineering

Publications

Department

2016

Prediction of local seismic damage in steel moment resisting

frames

Papia Sultana

Western University

Maged A. Youssef

Western University, youssef@uwo.ca

Follow this and additional works at: https://ir.lib.uwo.ca/civilpub

Part of the Structural Engineering Commons

Citation of this paper:

Sultana, Papia and Youssef, Maged A., "Prediction of local seismic damage in steel moment resisting frames" (2016). Civil and Environmental Engineering Publications. 197.

https://ir.lib.uwo.ca/civilpub/197 


\title{
Prediction of Local Seismic Damage in Steel Moment Resisting Frames
}

\author{
Papia Sultana ${ }^{a}$, Maged A. Youssef ${ }^{b}$
}

\begin{abstract}
Steel moment resisting frames (SMRFs) are widely utilized as a lateral load resisting system. Their seismic performance is usually assessed by examining the maximum value of inter-storey drift (MID) of all floors. The accuracy of such assessment is debatable given the wide spread of values of MID at collapse that exist in the literature. In this study, a simplified method to define the failure inter-storey drift for each floor of a SMRF is proposed. The method was validated with the experimental and analytical studies by other researchers. Three- and ten-storey SMRFs were considered to further validate the proposed method. The effects of the vertical and/or horizontal seismic components of five different ground motions on the SMRFs were evaluated using incremental dynamic analysis. The proposed method accurately identified the severely damaged floors of SMRFs.
\end{abstract}

Keywords: Seismic performance, Steel moment resisting frames, Inter-storey drift, Incremental dynamic analysis.

${ }^{a} \mathrm{PhD}$ Candidate, Western University, Civil and Environmental Engineering, London, ON, Canada N6A 5B9, Email: psultana@uwo.ca.

${ }^{\mathrm{b}}$ Professor, Western University, Civil and Environmental Engineering, London, ON, Canada N6A 5B9.

Corresponding author: Maged A. Youssef, Email: youssef@uwo.ca, Tel.: 519-661-2111 Ext. 88661. 


\subsection{INTRODUCTION}

Steel moment resisting frames (SMRFs) are widely used as the lateral load resistance system for mid- to high-rise buildings. After 1994 Northridge earthquake, significant research was conducted to improve their global seismic performance. While damage of individual elements (beams, columns, and connections) can be based on their rotations, damage to the full frame is usually related to the maximum inter-storey drift (MID). Reported MID values at collapse have large variations in the literature. While FEMA 356 [1] limited the MID for steel structures to 5\%, FEMA 350 [2] defined collapse of SMRFs in midrise buildings (4-12 storeys) to occur at $10 \%$ inter-storey drift. The New Zealand standard [3] limited the MID to 2.5\%. UBC 1997 [4] specified MID values of $2.5 \%$ and $2.0 \%$ for structures with short and long period of vibrations, respectively. The actual MID depends on many factors including design assumptions, characteristics of the ground motion, and effect of higher modes of vibrations.

The damage due to the vertical component of a seismic excitation was observed to be very significant by many researchers [5-7]. The interior columns and interior beams of momentresisting frames are significantly affected $[5,6]$. The increase in the column axial forces caused by the vertical excitation of near-field and far-field earthquakes can reach $65 \%$ and $8 \%$, respectively [7]. The fluctuation of column axial force can also increase the column's rotational ductility demand, and, thus cause significant structural damage [8]. Several building codes account for the vertical seismic component by assuming that the vertical design response spectra is $2 / 3$ of the horizontal design spectra [1, 4]. Eurocode 8 [9] and the National Earthquake Hazards Reduction Program [10] define the vertical spectrum independently from the horizontal spectrum. 
The relationship between seismic damage and inter-storey drift (ID) was examined in this study to allow identification of the severely damaged storeys without the need for conducting nonlinear incremental dynamic analysis (IDA). The study proposes a simplified method that can identify the severely damaged floors of SMRFs when exposed to an earthquake while accounting for the vertical seismic component.

\subsection{PROPOSED METHOD}

Youssef and Elfeki [11] proposed a simplified method to predict the ID at collapse for reinforced concrete frames. The method does not account for the P- $\Delta$ effect, which might be appropriate for concrete structures. In this study, the method is further extended to account for $\mathrm{P}-\Delta$ effect.

\subsection{Lateral drift $\left(\Delta_{m}\right)$ based on P- $\Delta$ effect:}

The increase of fixed-end moments and shear forces of columns due to the P- $\Delta$ effect are shown in Figure 1 and can be calculated using equations (1) and (2).

$$
\begin{gathered}
M_{f}=\frac{6 E_{s} I_{c}}{h_{c}^{2}} \Delta_{m}+\frac{P \Delta_{m}}{2} \\
V_{f}=\frac{12 E_{s} I_{c}}{h_{c}^{3}} \Delta_{m}+\frac{P \Delta_{m}}{h_{c}}
\end{gathered}
$$

Figure 2 shows an isolated column and the connecting beams. The figure assumes that: (1) joint rotations are equal for any two successive stories, (2) the stiffness of each beam is equally utilized by the columns above and below a specific floor (beams are split into hypothetical halves, each half possesses $50 \%$ of the stiffness of the original beam), and (3) 
Contra-flexure points are assumed to be at the mid-span of each beam and mid-height of each column [11-13]. The stiffness is presented in the figure by the ratio $K$ where $K=I / L$.

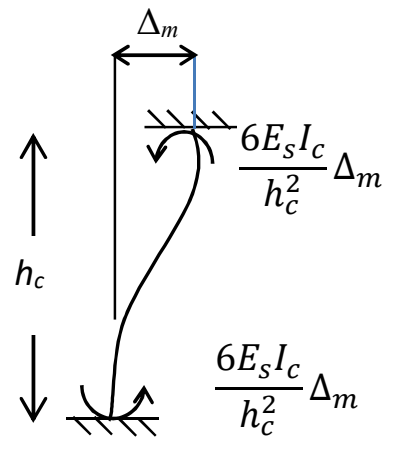

(a) Moment without axial force

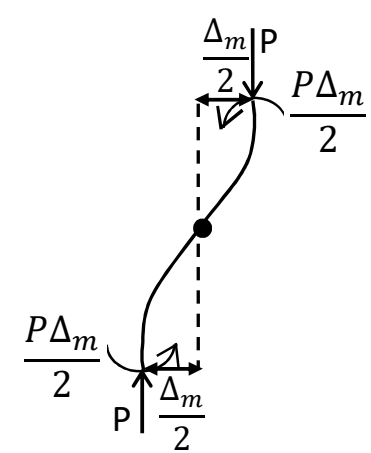

(b) P- $\Delta$ effect

Figure 1: Fixed-end moments induced by lateral displacement $\Delta_{m}$

If a relative lateral displacement $\Delta_{m}$ is applied between the column ends, the column fixed-end moment can be obtained using equation (1). As the flexural stiffness of the top beams and the column are $3 E_{s} K_{1}, 3 E_{s} K_{2}$ and $6 E_{s} K_{c}$, the moment distribution factor $d_{c t}$ can be calculated using equation (3). Applying the principal of moment distribution, the final moment at the column top $\left(M_{c t}\right)$ can be obtained using equations (4).

$d_{c t}=\frac{6 K_{c}}{3 K_{1}+3 K_{2}+6 K_{c}}=\frac{2}{K_{t}+2}$

Where $K_{t}=\frac{K_{1}+K_{2}}{K_{c}}$.

$M_{c t}=\left(\frac{6 E_{s} I_{c}}{h_{c}^{2}}+\frac{P}{2}\right) \Delta_{m} \frac{K_{t}}{K_{t}+2}$

Similarly, the moment at the bottom end of the column $\left(M_{c b}\right)$ can be calculated using equation (5).

$M_{c b}=\left(\frac{6 E_{s} I_{c}}{h_{c}^{2}}+\frac{P}{2}\right) \Delta_{m} \frac{K_{b}}{K_{b}+2}$ 
Where $K_{b}=\frac{K_{3}+K_{4}}{K_{c}}$

The values of $\Delta_{m}$ that lead to instability failure for each of the floor columns can be estimated using equations 4 and 5 .

\subsection{Lateral drift $\left(\Delta_{m}\right)$ based on storey-pushover analysis:}

The calculation for $\Delta_{m}$ in this section is based on pushover analysis, and, thus accounts for nonlinearity of the beams as well as the columns. For each storey, the columns are first assumed to be fixed at their lower ends, i.e. the lower storeys are removed. Gravity loads are then applied to the remaining storeys. Displacement-controlled pushover analysis is carried out at the level of the considered storey. The evaluated drift at collapse is then magnified to account for the rotation of the storeys below the considered one, which was initially ignored. The magnification factor $m$ was initially proposed by Muto [12] and later modified by Paulay and Priestley [13] and Youssef and Elfeki [11].

For equal inter-story drift, the shear force $V_{i}$ of a partially restrained column is lower than that of fixed-end column by a factor $\alpha$, equation (6). Replacing the values $V_{f}, M_{c t}$ and $M_{c b}$ in equation (6) by equations (2), (4), and (5), respectively, leads to equation (7). The drift magnification factor $m$ that can correlate the deformation of fully and partially restrained column is equal to $1 / \alpha$. Equation (8) was proposed by Youssef and Elfeki [11] to calculate average drift magnification factor $\left(m_{a v}\right)$ for each storey.

$$
\begin{aligned}
& V_{i}=\alpha V_{f}=\frac{M_{c t}+M_{c b}}{h_{c}} \\
& \propto=\frac{1}{2}\left(\frac{K_{t}}{K_{t}+2}+\frac{K_{b}}{K_{b}+2}\right)
\end{aligned}
$$


$m_{a v}=\frac{\sum \text { Stiffness of storey columns assuming fully fixed condition }}{\sum \text { Stiffness of storey columns assuming partially fixed condition }}$

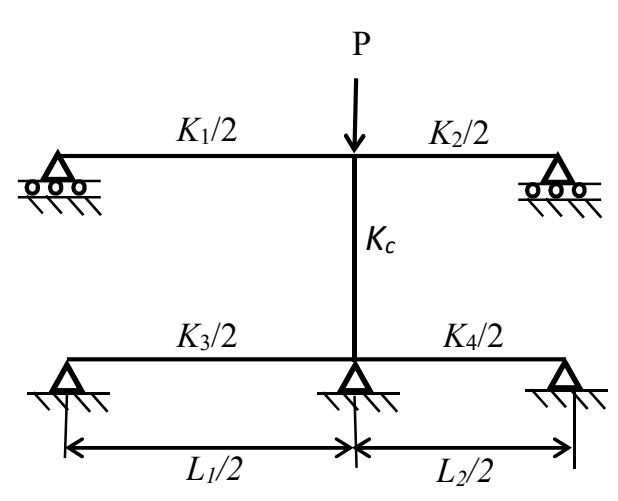

(a) Subframe idealization

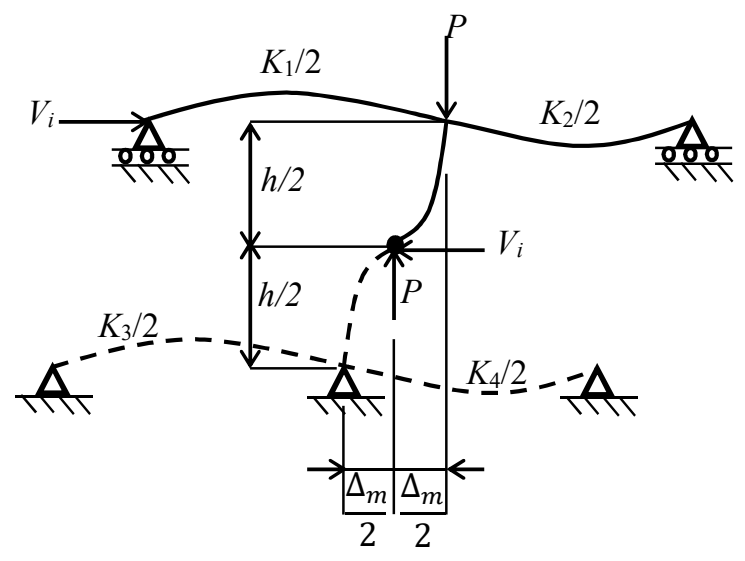

(b) Distortion of subframe

Figure 2: Isolated column and restraining beams

\subsection{Application of the proposed method}

The minimum of the two limiting drift values evaluated in sections 2.1 and 2.2 represent the drift value leading to failure either due soft storey mechanism or instability. Figure 3 shows application of the proposed method to the second storey of a three storey building. The columns of the second floor are first assumed fixed at their lower ends. Gravity loads are then applied on the floors above the considered floor. Displacement controlled pushover analysis is carried out to calculate the ID values at collapse for the considered storey. Failure is assumed when any of the floor columns reaches its ultimate rotation. The corresponding ID is magnified by the factor calculated using equation (8) to account for the rotation of the lower column ends. The drift leading to flexural failure of any of the storey's columns due to P- $\Delta$ effect is then calculated using equations (4) and (5). The minimum of the magnified drift and the drift evaluated based on the P- $\Delta$ effect is considered as the failure inter-storey drift (FID) for the considered storey. Inter- 
storey drift limit corresponding to yielding of columns (YDL) can also be evaluated using the same process.

\subsection{Vertical seismic component}

To account for the effect of the vertical seismic component, the FID is calculated while adding extra vertical loads on the considered storey and the stories above [14]. The extra vertical loads are estimated by multiplying the mass of each floor by the vertical design spectrum acceleration, which is assumed to be $2 / 3$ of the horizontal design spectrum acceleration $[1,4]$.

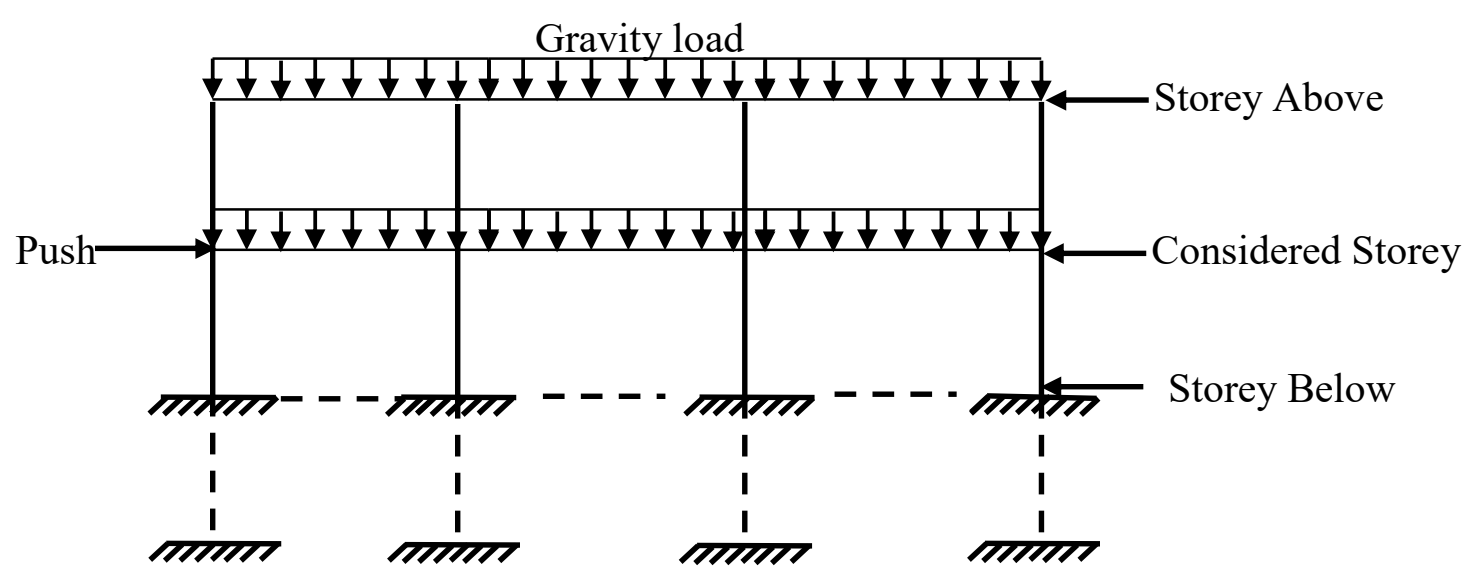

Figure 3: Proposed method to estimate inter-storey drift limits for the second storey of a three storey building.

\subsection{ASPECTS OF MODELING}

Moment resisting frames were modeled in this paper using SeismoStruct [15]. Beams and columns were modelled using displacement-based inelastic-frame elements. The number of elements was decided upon using a sensitivity analysis. Sample of the obtained results for different number of elements was presented in section 6.0. The distributed dead and live loads were converted to equivalent point loads that are applied at the nodes of each element. For 
example: for a beam divided to 4 elements, the equivalent point loads were applied at 5 nodes. This modeling technique was justified as the main behaviour was linked to the seismic loads. The vertical loads only affected the stiffness and capacity of the columns. Such modeling technique was employed by other researchers [16]. The mass of the building was also converted into lumped masses and applied at the nodes of each beam element. Bilinear material behaviour with $3 \%$ strain hardening [1] was considered using the distributed plasticity approach. The analysis accounts for P- $\Delta$ effect.

\subsection{Failure criteria}

FEMA 356 [1] proposed moment rotation behaviour for nonlinear analysis of steel beams and columns is shown in Figure 4. The parameter "a" defines the plastic rotation at ultimate condition. Values for this parameter are given in Table 1 . The yield rotation $\theta_{y}$ of beams and columns can be calculated using equations (9) and (10) [1]. The ultimate rotation $\left(\theta_{u}\right)$ can then be obtained by adding the plastic rotation to the yield rotation. Failure of a floor is defined when the rotation of any of its columns exceeds the ultimate rotation $\left(\theta_{\mathrm{u}}\right)$.

$$
\begin{aligned}
& \theta_{y}(\text { Beams })=\frac{Z F_{y e} L_{b}}{6 E I_{b}} \\
& \theta_{y}(\text { Columns })=\frac{Z F_{y e} L_{c}}{6 E I_{c}}\left(1-\frac{P}{P_{y e}}\right)
\end{aligned}
$$

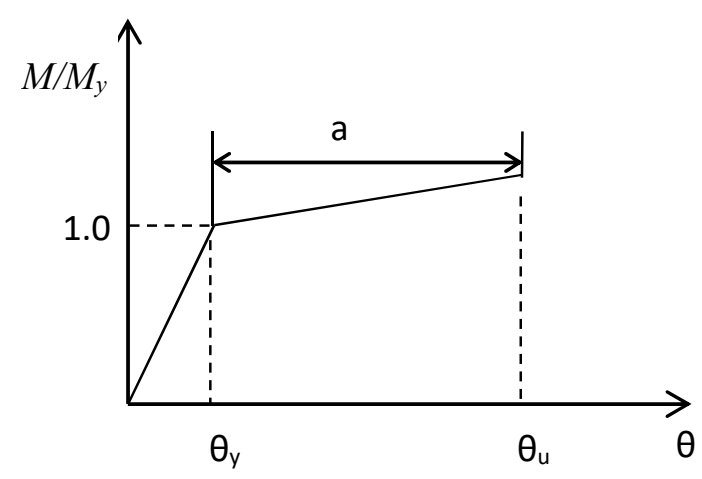

Figure 4: Moment-rotation behaviour for steel elements 
Table 1 Modeling parameters for nonlinear procedures according to FEMA356 [1].

\begin{tabular}{|c|c|}
\hline Component & $\begin{array}{c}\text { Plastic rotation } \\
\text { (radians) } \\
\mathrm{a}\end{array}$ \\
\hline 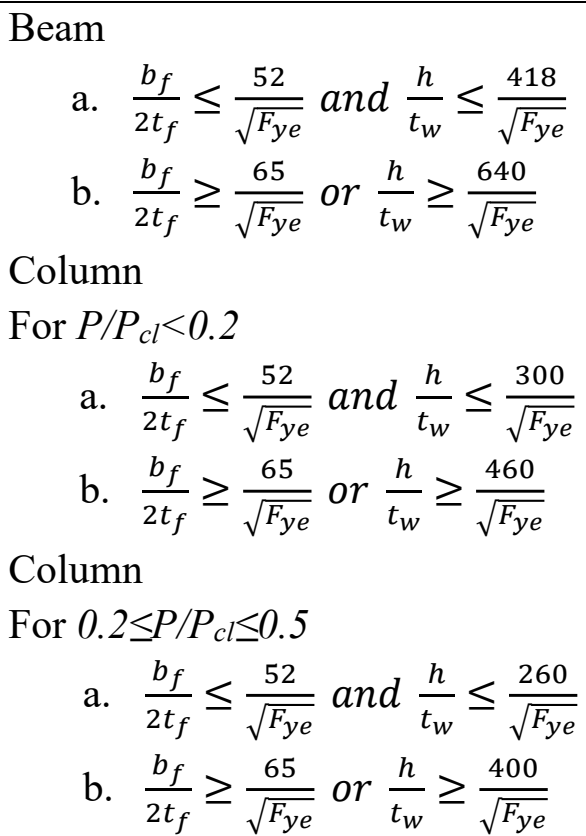 & $\begin{array}{c}11\left(1-1.7 P / P_{C L}\right) \theta_{y} \\
1 \theta_{y}\end{array}$ \\
\hline
\end{tabular}

\section{VALIDATION OF THE PROPOSED METHOD}

Suita et al. [17] performed a shake table test on a full scale 4-storey steel building. The moment resisting frames were designed and constructed according to the Japanese design specification (2008). The building was subjected to $0.4,0.6$ and 1.0 of the JR Takatori station record of the 1995 Hyogoken-Nanbu earthquake. The building collapsed due to soft first-storey mechanism at 1 time Takatori record. The maximum storey shear was reached at an inter-storey drift of $4 \%$. The proposed method was applied to estimate the FID and the location of the critical storey. Figure 5 compares the FID limits with the experimentally measured IDs at 1 times Takatori record. According to the proposed method the FID varied from $3.82 \%$ to $10.32 \%$ for the different stories. The FID of the $1^{\text {st }}$ storey $(3.82 \%)$ was almost equal to the experimental ID at collapse (4\%). The experimental ID values for the remaining stories were much lower than the 
predicted FID. This explained the experimental observation that severe damage was only observed in the $1^{\text {st }}$ storey.

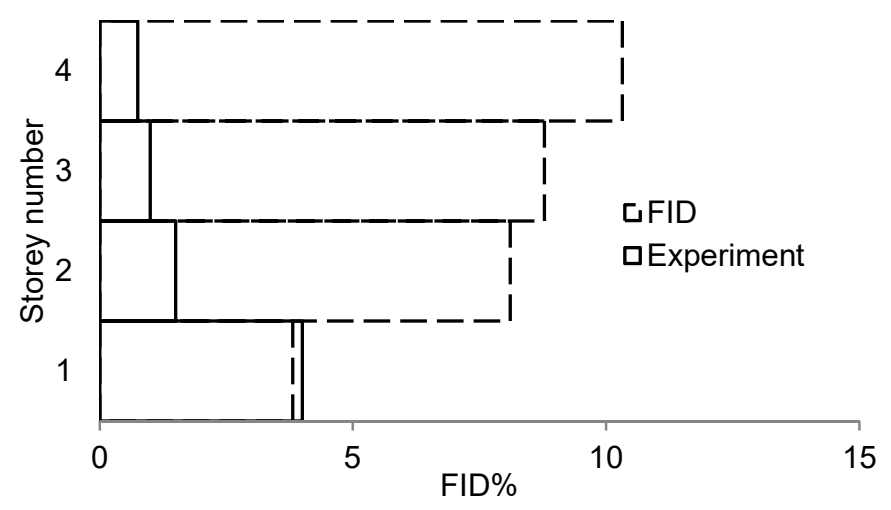

Figure 5: Estimated FID at collapse compared with the IDs measured by Suita et al. [17].

Hajjar et al. [18] performed a computational investigation on the Borax corporate headquarters building, a four-storey steel-frame structure. During 1994 Northridge earthquake, the $1^{\text {st }}$ and $2^{\text {nd }}$ floors of the building were severely damaged. The maximum inter-storey displacement-ductility demands were estimated using 3-D dynamic analysis as 2.81, 2.84, 2.01, and 1.88 for the $1^{\text {st }}, 2^{\text {nd }}, 3^{\text {rd }}$ and $4^{\text {th }}$ storey, respectively. The proposed method was applied to the north-south moment frame to calculate the FID for each storey. The FID limits for the $1^{\text {st }}, 2^{\text {nd }}$, $3^{\text {rd }}$, and $4^{\text {th }}$ floors were $6.96 \%, 9.85 \%, 10.86 \%$ and $13.46 \%$, respectively. The lowest value of FID indicated that failure was expected to occur at the first floor, which agreed with the observed damage distribution of the frame due to Northridge earthquake [18].

Kim et al. [19] experimentally investigated the inelastic nonlinear behaviour of a one-bay two-story steel frame subjected to Northridge and Loma Prieta earthquakes. The experimental ID for the $1^{\text {st }}$ and $2^{\text {nd }}$ stories were $2.22 \%$ and $1.85 \%$ due to Northridge earthquake, and $1.75 \%$ and $1.46 \%$ due to Loma Prieta earthquake. The measured strains revealed that the first storey columns yielded for both earthquakes. The yielding inter-storey drift (YDL) of each storey was 
calculated. The calculated YDL were $1.1 \%$ and $1.8 \%$ for the $1^{\text {st }}$ and $2^{\text {nd }}$ storey, respectively. Comparing the proposed YDL and the experimental ID showed that ID of the $1^{\text {st }}$ storey exceeded the limit, and, thus yielding of columns occurred. The ratio of the experimental ID to the YDL for the $1^{\text {st }}$ floor was 2.02 for the case of Northridge earthquake, which explained the severe plastic strains observed during the experiment.

\subsection{CASE STUDY}

A three-storey (Frame 3) and a ten-storey (Frame 10) SMRFs were selected to further validate the proposed method. The 3-storey building was designed by a consulting engineering firm [20]. Figure 6 shows the plan and elevation of the building. The solid lines indicate the locations of the moment frames. The design yield strengths of the beams and columns were 248 $\mathrm{MPa}$ and $345 \mathrm{MPa}$, respectively. The 10-storey building (Figure 7) was designed by Ozhendekci et al. [21]. The design yield strength was $355 \mathrm{MPa}$. Sections for Frames 3 and Frame 10 are listed in Tables 2 and 3.

A 2D model of the SMRFs was developed using SeismoStruct. As the axial load of the columns was expected to be less than $50 \%$ of their capacity, displacement-based pushover analysis was performed to evaluate the FIDs for each storey. The drift magnification factors $\left(m_{a v}\right)$ to account for rotations of storeys below the considered storey are listed in Tables 4 and 5. The drifts at which the internal and external columns reached their ultimate moment capacity due to P- $\Delta$ effect were then calculated using equations (4) and (5) and are also listed in Tables 4 and 5. The FID for the upper storeys increased because of the rotation of the storeys below. 
Table 2 Section properties of Frame 3

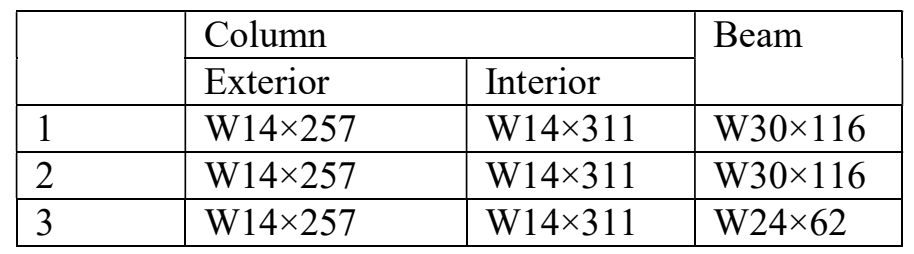

Table 3 Section properties of Frame 10

\begin{tabular}{|c|c|c|}
\hline Storey & Column & Beam \\
\hline 1 & HEM550 & IPE550 \\
\hline 2 & HEM550 & IPE600 \\
\hline 3 & HEM550 & IPE600 \\
\hline 4 & HEM550 & IPE600 \\
\hline 5 & HEM500 & IPE600 \\
\hline 6 & HEM500 & IPE550 \\
\hline 7 & HEM500 & IPE550 \\
\hline 8 & HEM400 & IPE550 \\
\hline 9 & HEM400 & IPE450 \\
\hline 10 & HEM400 & IPE450 \\
\hline
\end{tabular}

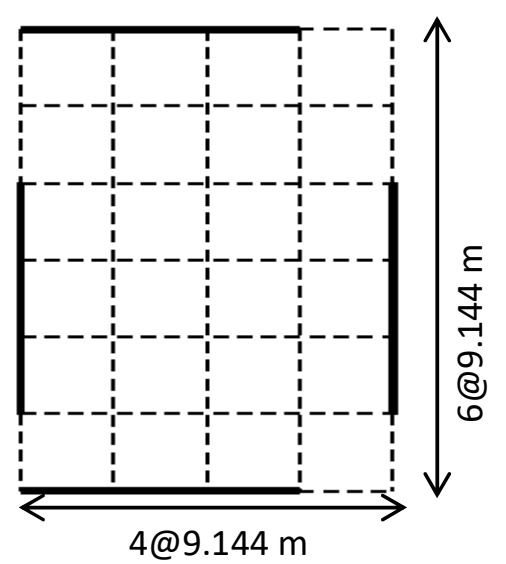

(a) Plan view

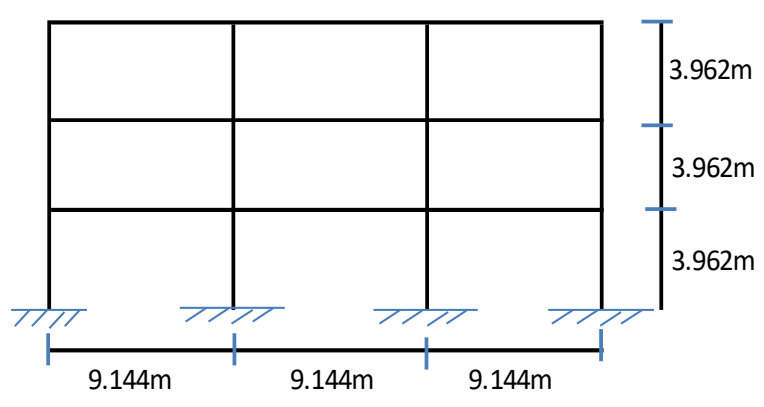

(b) Elevation

Figure 6: Plan and elevation of selected 3-storey building [20] 


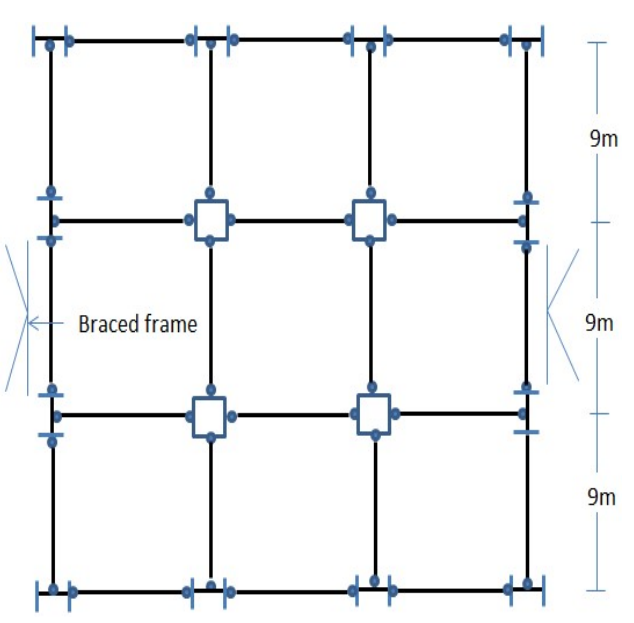

(a) Plan view

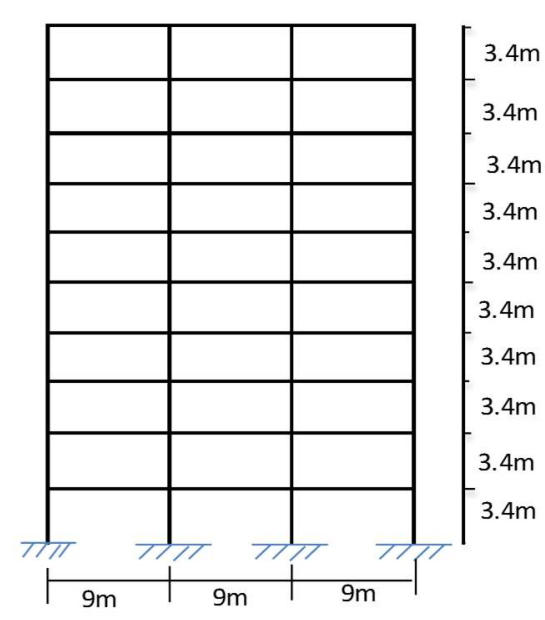

(b) Elevation

Figure 7: Plan and elevation of selected 10-storey building [21]

Table 4: Limiting FID (\%) for different floors of 3 storey frame

\begin{tabular}{|c|c|c|c|c|c|}
\hline Level & \multirow{2}{*}{$\begin{array}{c}\text { Drift } \\
\text { magnification } \\
\text { factor }\left(m_{a v}\right)\end{array}$} & $\begin{array}{c}\text { Limiting ID\% } \\
\text { according to } \\
\text { section 2.2 }\end{array}$ & \multicolumn{2}{|l|}{ Limiting ID\% based on section 2.1 } & Proposed \\
\cline { 4 - 5 } & & & Interior column & Exterior column & \\
\hline 1 & 1 & $\mathbf{6 . 0 4}$ & 6.39 & 6.49 & 6.04 \\
\hline 2 & 3.45 & $\mathbf{2 1 . 0 6}$ & 21.89 & 31.46 & 21.06 \\
\hline 3 & 4.94 & 30.50 & $\mathbf{2 2 . 8 9}$ & 71.62 & 22.89 \\
\hline
\end{tabular}

Table 5: Limiting FID (\%) for different floors of 10 storey frame

\begin{tabular}{|c|c|c|c|c|c|}
\hline Storey & $\begin{array}{c}\text { Drift } \\
\text { magnification }\end{array}$ & $\begin{array}{c}\text { Limiting ID \% } \\
\text { based on } \\
\text { factor }\left(m_{a v}\right)\end{array}$ & \multicolumn{2}{|l|}{ Limiting ID\% based on section 2.1 } & $\begin{array}{c}\text { Proposed } \\
\text { section } 2.2\end{array}$ \\
\cline { 4 - 5 } & & & Interior column & Exterior column & \\
\hline 1 & 1 & $\mathbf{2 . 3 8}$ & 3.73 & 4.98 & 2.38 \\
\hline 2 & 9.90 & 31.6 & $\mathbf{3 1 . 1}$ & 60.5 & 31.1 \\
\hline 3 & 8.69 & $\mathbf{2 8 . 6}$ & 32.7 & 59.4 & 28.6 \\
\hline 4 & 8.69 & $\mathbf{2 9 . 4}$ & 34.4 & 58.3 & 29.4 \\
\hline 5 & 7.31 & $\mathbf{2 7 . 7}$ & 30.9 & 51.5 & 27.7 \\
\hline 6 & 8.31 & 32.3 & $\mathbf{3 0 . 7}$ & 51.9 & 30.7 \\
\hline 7 & 9.62 & 38.5 & $\mathbf{3 7 . 9}$ & 66.1 & 37.9 \\
\hline 8 & 6.56 & 32.9 & $\mathbf{3 0 . 0}$ & 52.0 & 29.9 \\
\hline 9 & 8.48 & 43.7 & $\mathbf{3 1 . 2}$ & 55.4 & 31.2 \\
\hline 10 & 12.0 & 63.4 & $\mathbf{5 0 . 6}$ & 94.5 & 50.6 \\
\hline
\end{tabular}




\subsection{PUSHOVER ANALYSIS}

The lateral load distribution for the pushover analysis was assumed as the elastic base shear distribution. Different number of elements was considered in the analysis. Figure 8 shows results of pushover analysis for Frame 3 considering two mesh sizes, dividing beams and columns into 4 and 2 elements (Model 1) and dividing them into 6 and 4 elements (Model 2), respectively. The comparison of the base shear versus the roof drift curves for the two models is shown in Figure 8 (a). It leaded to the conclusion that the number of elements in model 1 was adequate. For both models, the frame failed at a roof drift of $6.71 \%$ due to failure of a first floor column. Figure 8 (b) shows the comparison between the ID of different floors and the proposed FID. Although the maximum ID (7.17\%) occurred at the $2^{\text {nd }}$ floor, none of the floor columns failed. This agrees with the proposed method as the ID for this floor was lower than the FID. Figure 8(c) shows the damage distribution at failure. The four columns of the first floor exceeded the yield strain at their base. The exterior column reached its ultimate rotation. Yielding of beams was observed for all floors. Columns of the $2^{\text {nd }}$ and $3^{\text {rd }}$ storeys did not experienced any yielding.

Figure 9 shows the results of pushover analysis for Frame 10. The frame failed at $2.98 \%$ roof drift. The lower ends of $1^{\text {st }}$ floor columns and $2^{\text {nd }}$ floor interior columns yielded. Two columns of the $1^{\text {st }}$ first floor failed as shown in Figure 9 (c). Although the MID occurred at the third floor, its value was much lower than the predicted FID for that floor. The observed damage at collapse supported this fact as the $3^{\text {rd }}$ floor columns did not experience any yielding. From the pushover analysis of both frames, it was observed that the storey experiencing the MID is not the critical storey and that the proposed method can accurately predict the drift limit for the critical storey. 


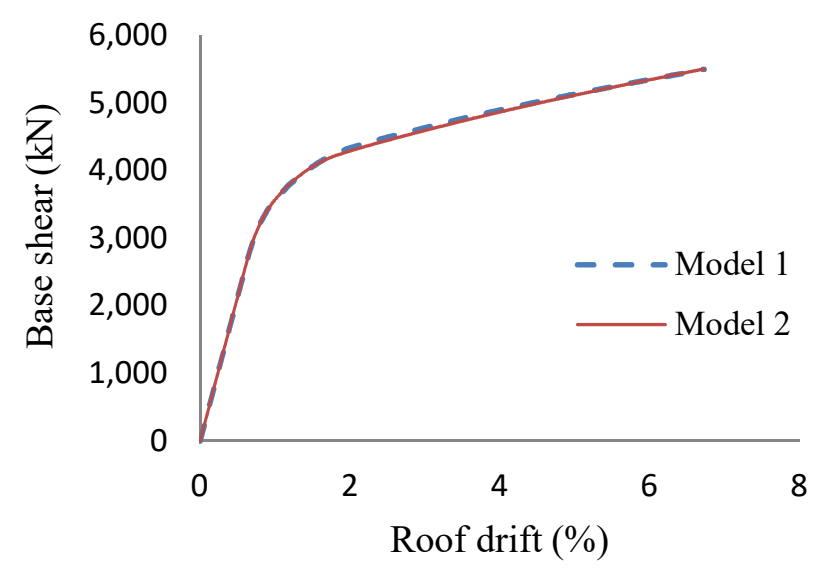

(a)

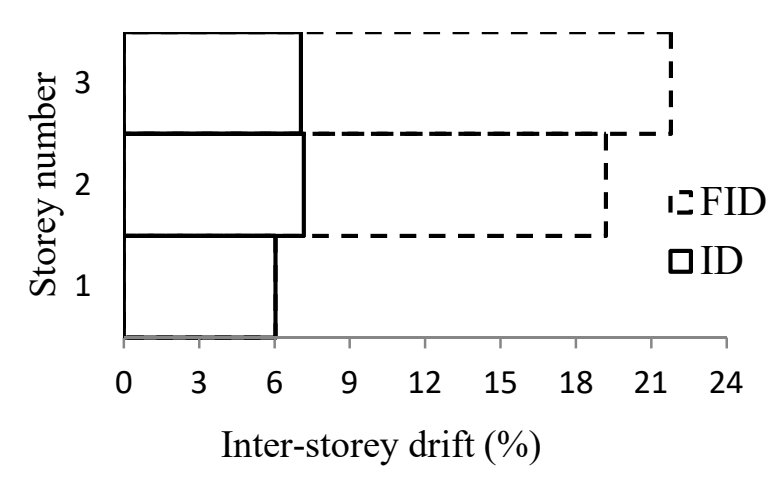

(b)

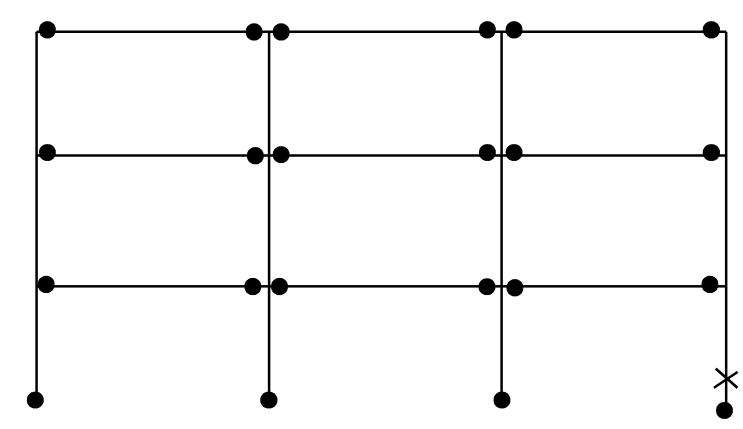

- Yielding $\times$ Failure

(c)

Figure 8: Pushover analysis results for Frame 3 (a) Relationship between base shear and roof drift, (b) ID obtained from pushover analysis as compared with the proposed collapse ID limits (c) Observed damage at collapse.

\subsection{DYNAMIC ANALYSIS}

The seismic performance of the considered frames depends on the seismic hazard parameters including frequency content, event duration and effective number of loading cycles. Five different ground motions were selected to conduct IDA analysis. They were obtained from PEER ground motion database [22] and their characteristics are listed in Table 6. Figure 10 shows the elastic response spectra considering $5 \%$ damping for these selected ground motions. 
Eigen value analysis was performed to determine the frequencies and mode shapes for the considered frames. The fundamental horizontal and vertical periods of vibration of Frame 3 are $0.338 \mathrm{sec}$. and $0.114 \mathrm{sec}$, respectively, and those for Frame 10 are equal to $2.385 \mathrm{sec}$. and 0.277 sec., respectively.

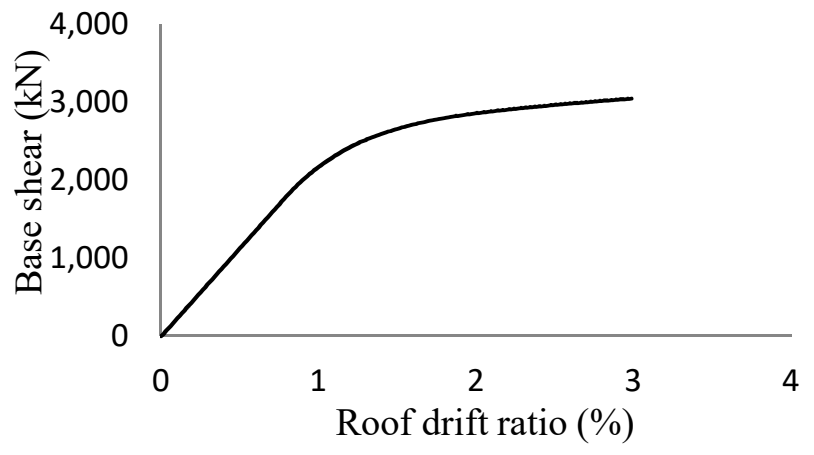

(a)

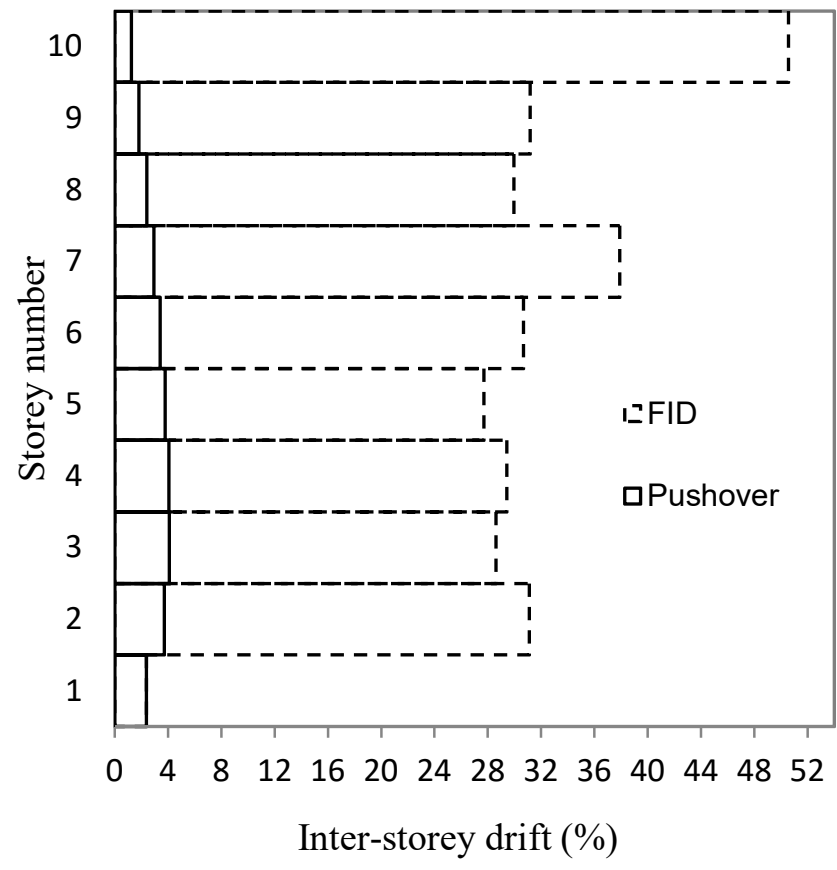

(b)

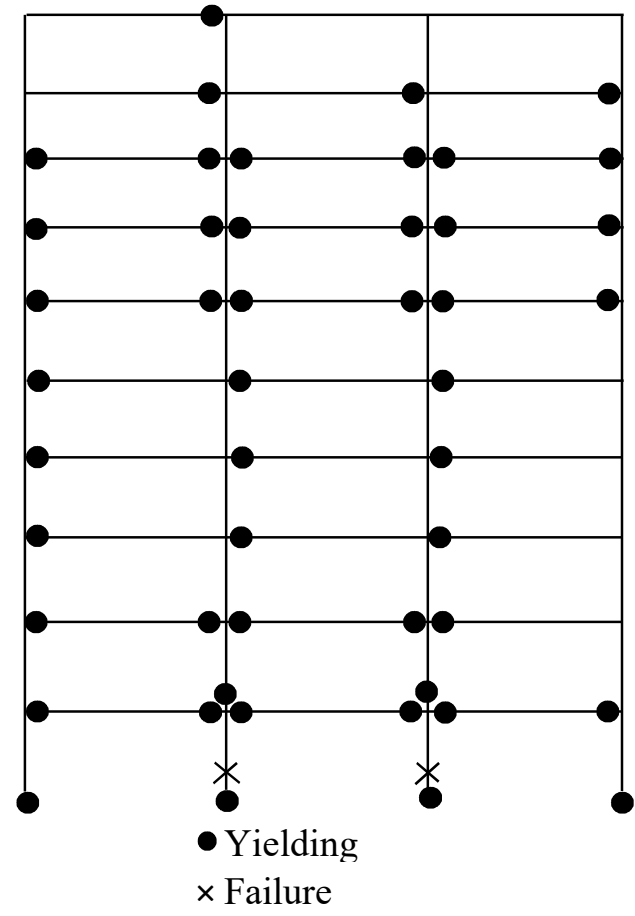

(c)

Figure 9: Pushover analysis results for Frame 10 (a) Relationship between base shear and roof drift, (b) ID obtained from pushover analysis as compared with the proposed collapse ID limits (c) Observed damage at collapse. 
IDA was performed to further validate the proposed method. IDA was first performed considering the horizontal components of five ground motions. The analysis was then repeated while considering both the horizontal and vertical seismic components. The vertical components were scaled using the same scaling factor as the horizontal components to keep the $\mathrm{V} / \mathrm{H}$ ratio constant. IDA analysis was terminated when the proposed FID limit was reached at any floor. The MIDs of both frames for the five different ground motions are listed in Table 7. It is observed that the MID does not necessary occur at the same storey for the different ground motions and that application of the vertical component can change the storey experiencing the MID.

Table 6: Characteristics of ground motions

\begin{tabular}{|c|c|c|c|c|c|}
\hline Earthquake & Date & $\mathrm{M}_{\mathrm{s}}$ & Station & \multicolumn{2}{|c|}{ PGA( g) } \\
\cline { 3 - 6 } & & magnitude & & Horizontal & Vertical \\
\hline Northridge & January 17, 1994 & 6.7 & Arleta-Nordhoff & 0.344 & 0.438 \\
\hline Imperial Valley & October 15, 1979 & 6.9 & El Centro Array \#6 & 0.439 & 1.655 \\
\hline Loma Prieta & October 18, 1989 & 7.1 & Capitola & 0.451 & 0.5411 \\
\hline Tabas & September 16, 1978 & 6.9 & Tabas & 0.852 & 0.688 \\
\hline San Fernando & February 2, 1971 & 6.6 & Pacoima dam & 1.23 & 0.699 \\
\hline
\end{tabular}

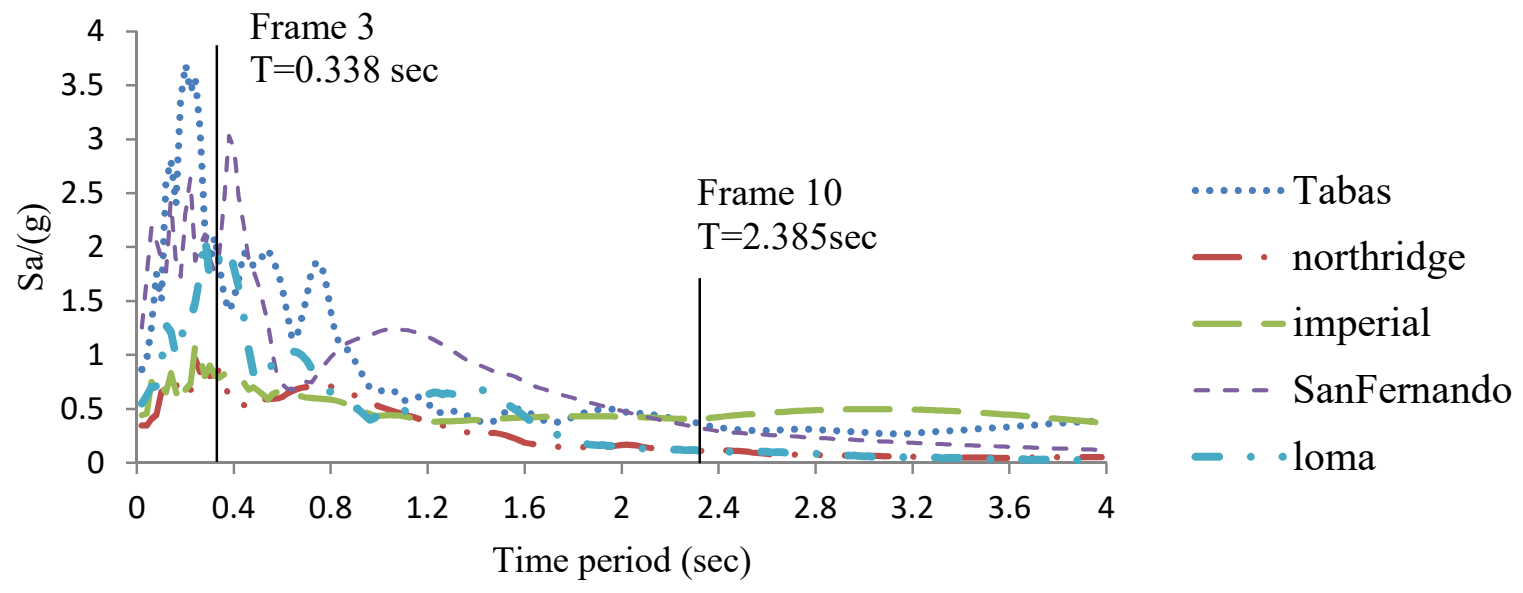

Figure 10: Elastic response spectral acceleration for horizontal seismic component 
Table 7: MID at different ground motions

\begin{tabular}{|c|c|c|c|c|}
\hline \multirow[t]{2}{*}{ Ground motion } & \multicolumn{2}{|c|}{ Frame 3} & \multicolumn{2}{|c|}{ Frame 10} \\
\hline & $\begin{array}{c}\text { MID } \\
\text { (Horizontal } \\
\text { component) }\end{array}$ & $\begin{array}{c}\text { MID } \\
\text { (Horizontal } \\
\text { and vertical } \\
\text { component) }\end{array}$ & $\begin{array}{c}\text { MID } \\
\text { (Horizontal } \\
\text { component) }\end{array}$ & $\begin{array}{c}\text { MID } \\
\text { (Horizontal and } \\
\text { vertical } \\
\text { component) }\end{array}$ \\
\hline Imperial valley & $\begin{array}{c}7.13 \% \\
\left(2^{\text {nd }} \text { storey }\right)\end{array}$ & $\begin{array}{c}7.19 \% \\
\left(3^{\text {rd }} \text { storey }\right)\end{array}$ & $\begin{array}{c}3.46 \% \\
\left(2^{\text {nd }}, 3^{\text {rd }} \text { storey }\right)\end{array}$ & $\begin{array}{c}2.35 \% \\
\left(4^{\text {th }} \text { storey) }\right.\end{array}$ \\
\hline Northridge & $\begin{array}{c}6.45 \% \\
\left(2^{\text {nd }} \text { storey }\right)\end{array}$ & $\begin{array}{c}7.19 \% \\
\left(3^{\text {rd }} \text { storey }\right)\end{array}$ & $\begin{array}{c}3.57 \% \\
\left(3^{\text {rd }} \text { storey }\right)\end{array}$ & $\begin{array}{c}2.70 \% \\
\left(8^{\text {th }} \text { storey }\right)\end{array}$ \\
\hline Tabas, Iran & $\begin{array}{c}6.94 \% \\
\left(3^{\text {rd }} \text { storey }\right)\end{array}$ & $\begin{array}{c}7.09 \% \\
\left(3^{\text {rd }} \text { storey }\right)\end{array}$ & $\begin{array}{c}3.51 \% \\
\left(4^{\text {th }} \text { storey }\right)\end{array}$ & $\begin{array}{c}2.38 \% \\
\left(4^{\text {th }} \text { storey) }\right.\end{array}$ \\
\hline San Fernando & $\begin{array}{c}7.47 \% \\
\left(3^{\text {rd }} \text { storey) }\right.\end{array}$ & $\begin{array}{c}7.66 \% \\
\left(3^{\text {rd }} \text { storey }\right)\end{array}$ & $\begin{array}{c}2.99 \% \\
\left(2^{\text {nd }}, 5^{\text {th }} \text { storey }\right)\end{array}$ & $\begin{array}{c}2.53 \% \\
\left(7^{\text {th }} \text { storey }\right)\end{array}$ \\
\hline Loma Prieta & $\begin{array}{c}8.33 \% \\
\left(3^{\text {rd }} \text { storey }\right)\end{array}$ & $\begin{array}{c}7.91 \% \\
\left(3^{\text {rd }} \text { storey }\right)\end{array}$ & $\begin{array}{c}5.42 \% \\
\left(8^{\text {th }} \text { storey }\right)\end{array}$ & $\begin{array}{c}3.63 \% \\
\left(8^{\text {th }} \text { storey }\right)\end{array}$ \\
\hline
\end{tabular}

\subsection{Building damage considering the horizontal components}

The damage distribution of Frame 3 at failure considering the horizontal component of Imperial Valley earthquake $[\mathrm{Sa}(\mathrm{T} 1)=10.10 \mathrm{~g}]$ is shown in the Figure 11(a). It is observed that all beams yielded and three of the $1^{\text {st }}$ floor columns reached the collapse rotation. The damage distribution clearly shows that the $1^{\text {st }}$ storey was severely damaged as compared to the other floors. Figure 11(b) shows the comparison between the ID of different storeys with the predicted FID limits. Although the IDs of the $2^{\text {nd }}$ and $3^{\text {rd }}$ stories were higher than that of the $1^{\text {st }}$ storey, columns of those storeys did not experience any yielding. This agrees with the predicted limit as the ID for the $1^{\text {st }}$ storey was equal to the predicted limit (6.04\%) and the ID for the other storeys were much lower than the FIDs.

Figures 12-15 show the results of dynamic analysis of Frame 3 at failure considering the horizontal components of Loma $[\mathrm{Sa}(\mathrm{T} 1)=32.71 \mathrm{~g}]$, Northridge $[\mathrm{Sa}(\mathrm{T} 1)=13.92 \mathrm{~g}]$, San Fernando $[\mathrm{Sa}(\mathrm{T} 1)=17.1 \mathrm{~g}]$ and Tabas $[\mathrm{Sa}(\mathrm{T} 1)=14.75 \mathrm{~g}]$ earthquakes. All four columns of the $1^{\text {st }}$ storey 
yielded and three of them failed. Columns of the $2^{\text {nd }}$ and $3^{\text {rd }}$ storeys experienced some yielding in the case of Loma and San Fernando records. However, they did not reach the failure state. Although, the damage distribution highlights that the $1^{\text {st }}$ storey was the severely damaged storey, the MIDs occurred at a different storey considering the four records as shown in Figures 12(b) 13(b), 14(b) and 15(b). Reaching the FID limit of the $1^{\text {st }}$ storey reflects that the storey was severely damaged, which agreed with the observed damage condition.

Results of the dynamic analysis at failure of Frame 10 are presented in Figures 16 to 20 considering the horizontal components of the ground motions. Figure 16(a) shows that all of the $1^{\text {st }}$ floor columns and the interior columns of the $2^{\text {nd }}$ floor yielded due to Imperial earthquake $[\mathrm{Sa}(\mathrm{T} 1)=0.348 \mathrm{~g}]$. One interior column of the $1^{\text {st }}$ storey failed. Although the MID was at the $2^{\text {nd }}$ and $3^{\text {rd }}$ storeys, failure does not occur at these levels. This agreed with the limits predicted using the proposed method as the ID of the first floor was almost equal to the predicted limit $(2.38 \%)$ and the IDs for the $2^{\text {nd }}$ or $3^{\text {rd }}$ floor $(3.46 \%)$ were much lower than the predicted limits.

Figures 17 to 20 show that three columns of the $1^{\text {st }}$ floor failed due to the horizontal components of Northridge, Tabas and San Fernando earthquakes and one column failed in case of Loma earthquake. MID drift (5.42\%) occurred at the $8^{\text {th }}$ floor considering the horizontal component of Loma earthquake. Figure 20 (a) shows that this floor was not critical as none of its columns failed. Same observations can be made considering other records. 


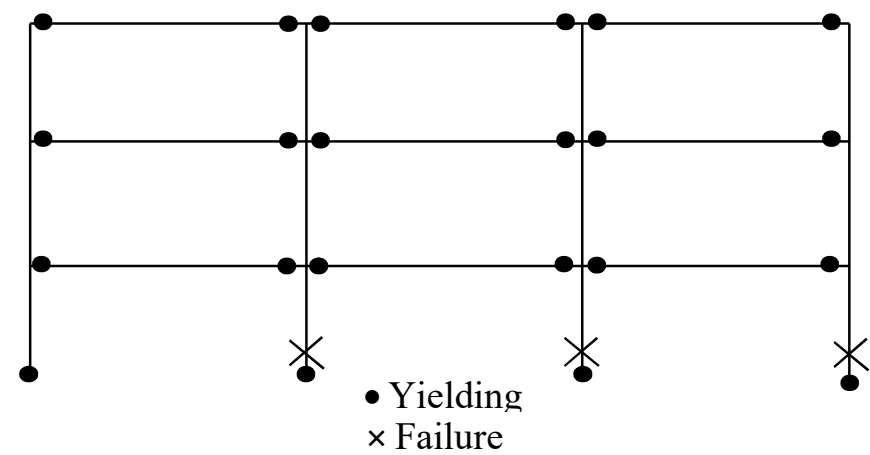

(a)

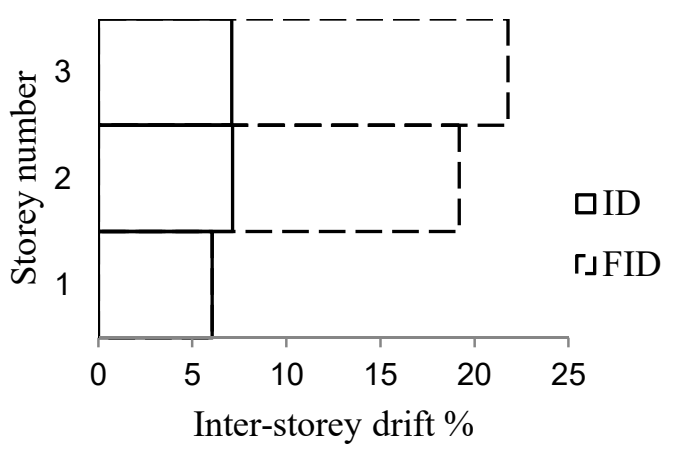

(b)

Figure 11: Results of Frame 3 considering horizontal component of Imperial earthquake at $\mathrm{Sa}(\mathrm{T} 1)=$ $10.10 \mathrm{~g}$ (a) Distribution of yielding (b) ID compared with FID limits

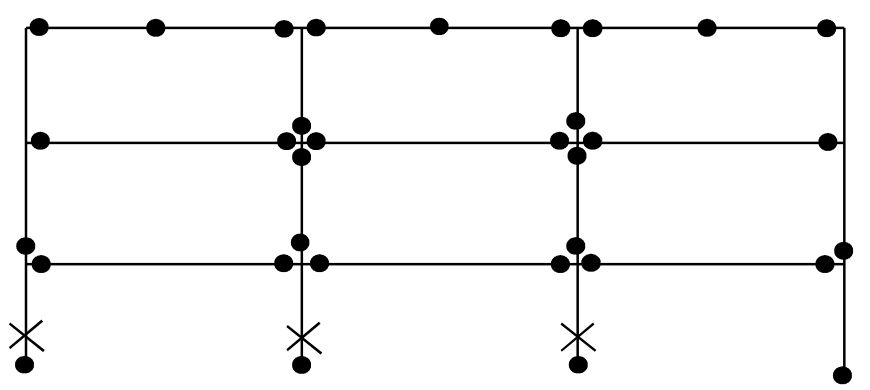

- Yielding

$\times$ Failure

(a)

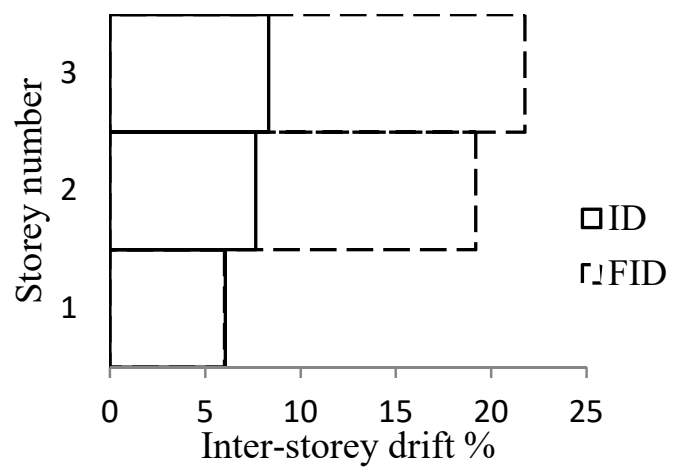

(b)

Figure 12: Results of Frame 3 considering horizontal component of Loma earthquake at Sa(T1) $=32.71 \mathrm{~g}$ (a) Distribution of yielding (b) ID compared with FID limits.

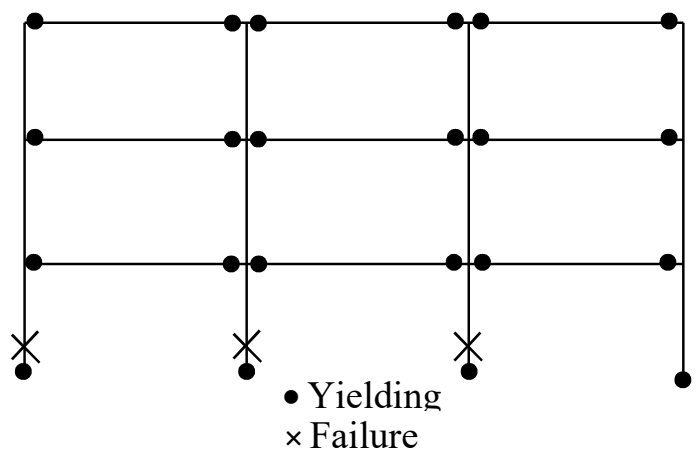

(a)

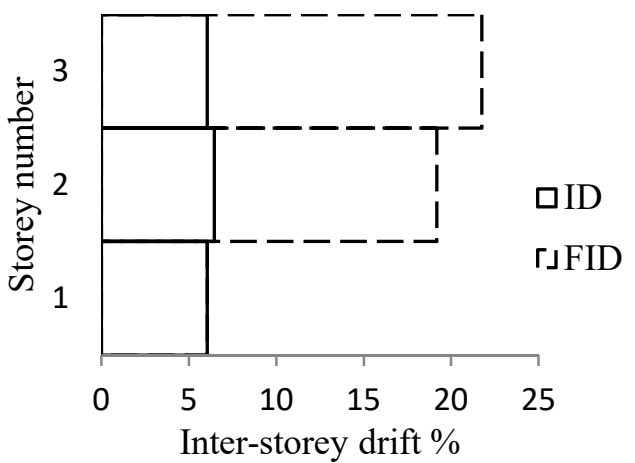

(b)

Figure 13: Results of Frame 3 considering horizontal component of Northridge earthquake at $\mathrm{Sa}(\mathrm{T} 1)=$ 13.92g (a) Distribution of yielding (b) ID compared with FID limits. 


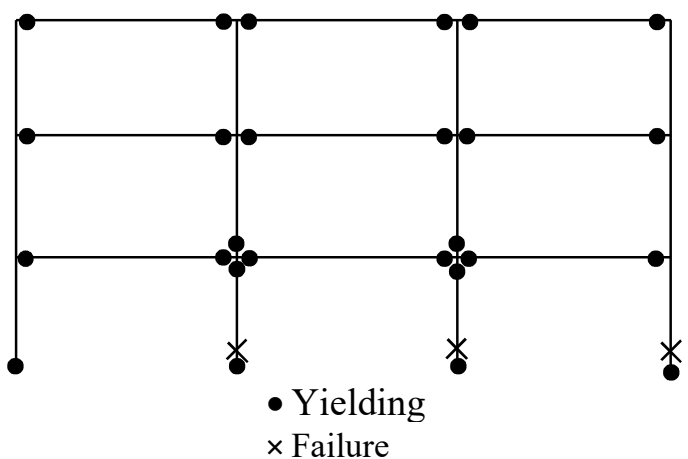

(a)

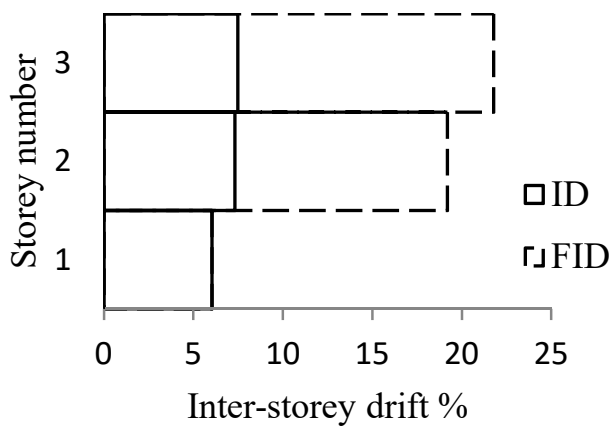

(b)

Figure14: Results of Frame-3 considering horizontal component of San Fernando earthquake at $\mathrm{Sa}(\mathrm{T} 1)=$ 17.1g (a) Distribution of yielding (b) ID compared with FID limits.

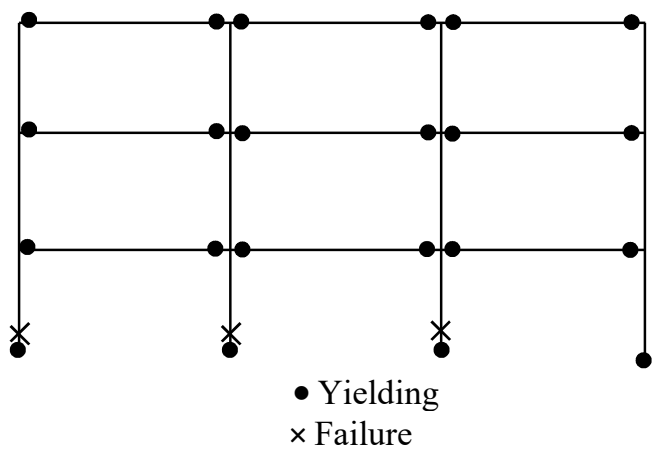

(a)

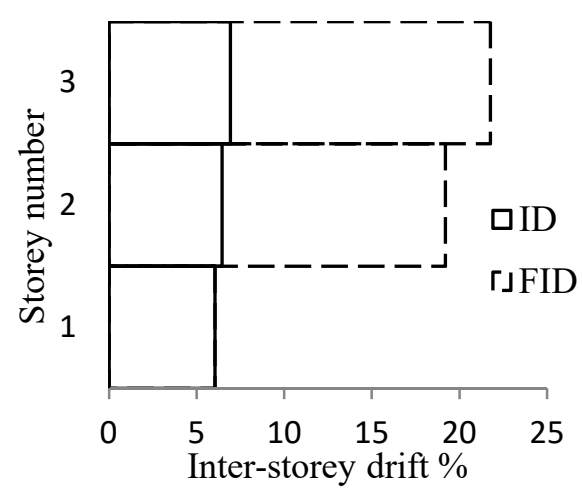

(b)

Figure 15: Results of Frame 3 considering horizontal component of Tabas earthquake at $\mathrm{Sa}(\mathrm{T} 1)=14.75 \mathrm{~g}$ (a) Distribution of yielding (b) ID compared with FID limits. 


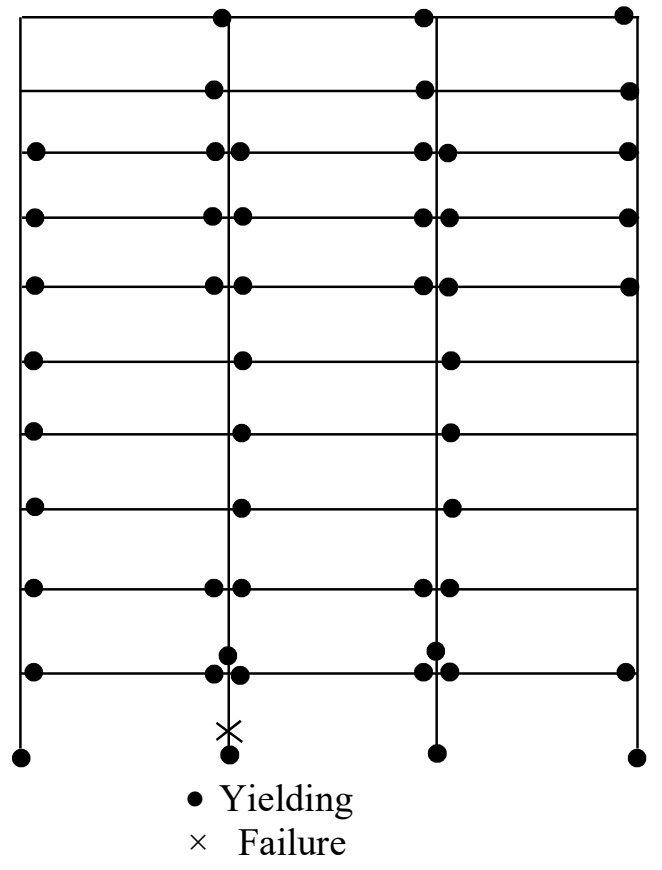

(a)

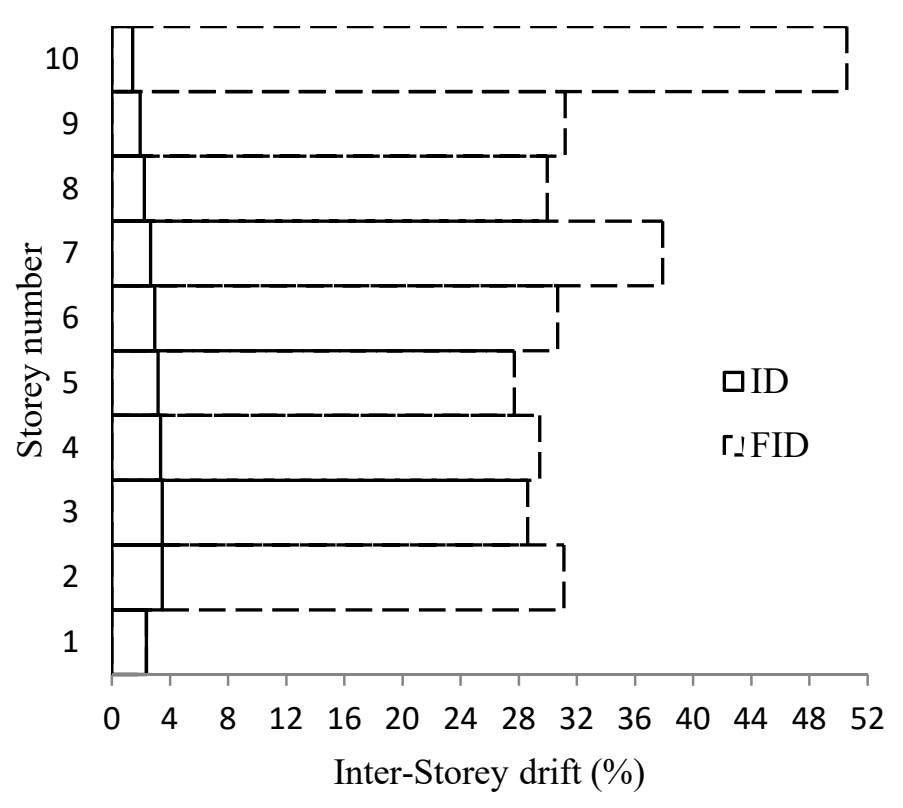

(b)

Figure 16: Results of Frame 10 considering horizontal component of Imperial earthquake at $\mathrm{Sa}(\mathrm{T} 1)=$ $0.348 \mathrm{~g}$ (a) Distribution of yielding (b) ID compared with FID limits.

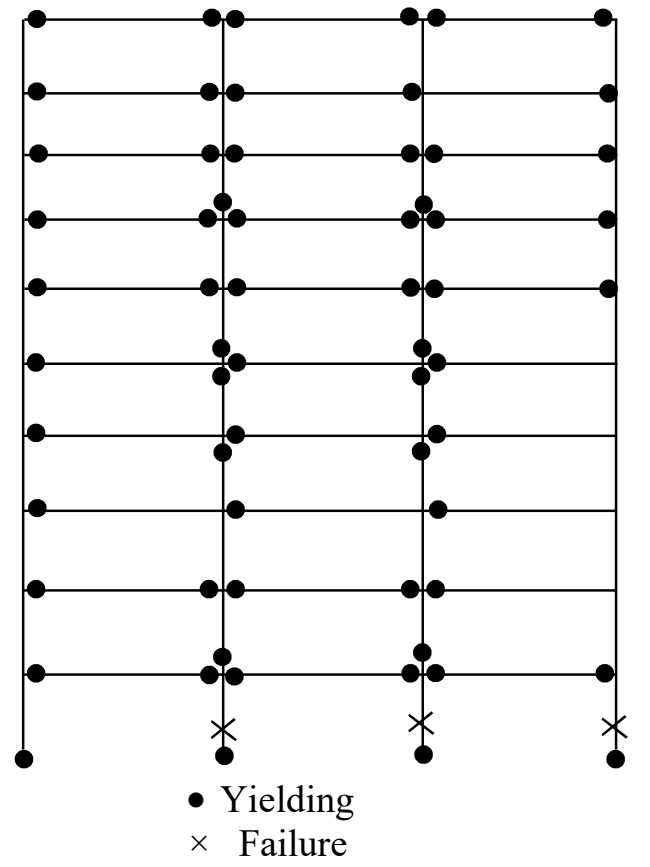

(a)

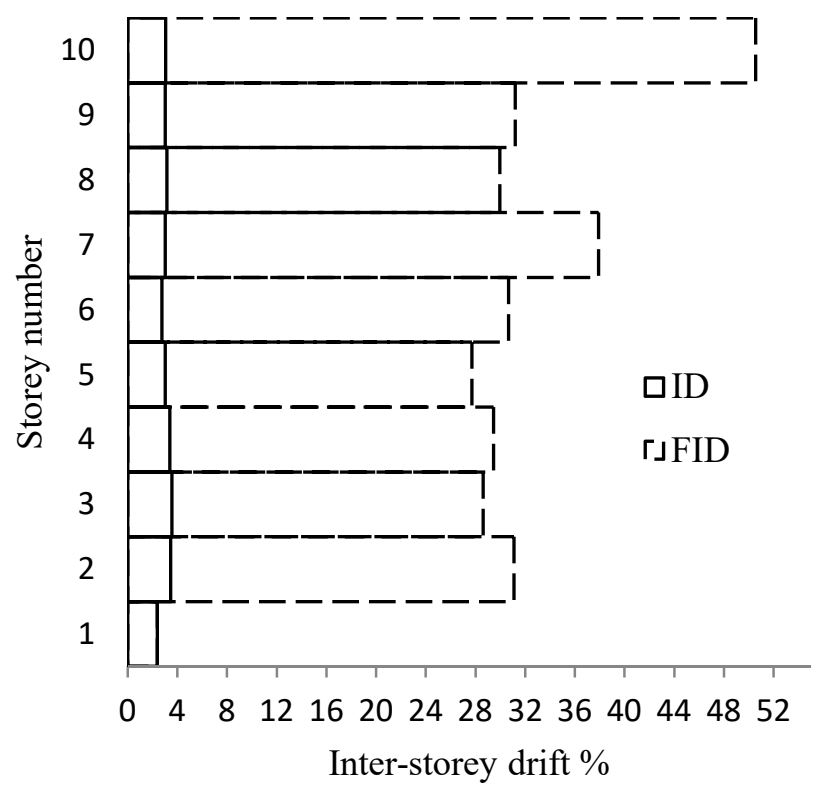

(b)

Figure 17: Results of Frame 10 considering horizontal component Northridge earthquake at $\mathrm{Sa}(\mathrm{T} 1)=$ $0.424 \mathrm{~g}$ (a) Distribution of yielding (b) ID compared with FID limits. 


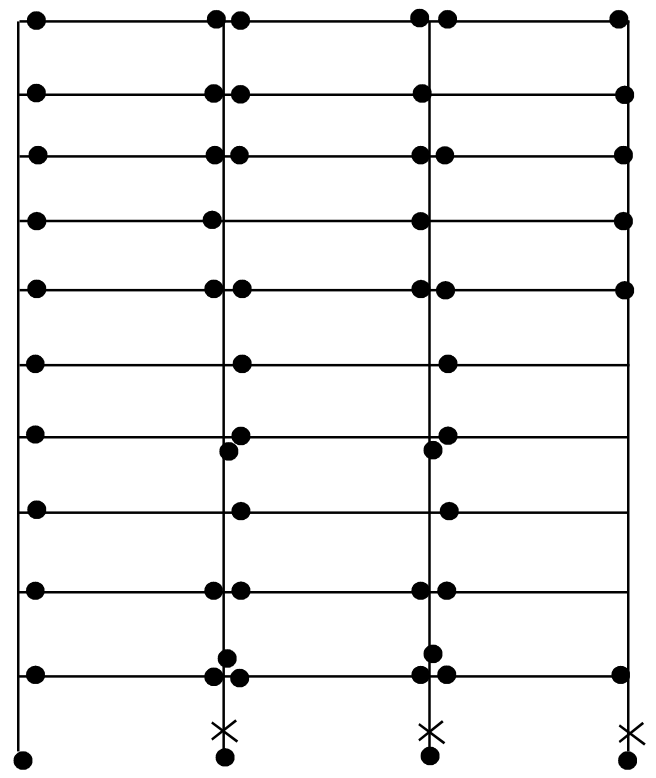

- Yielding

$\times$ Failure

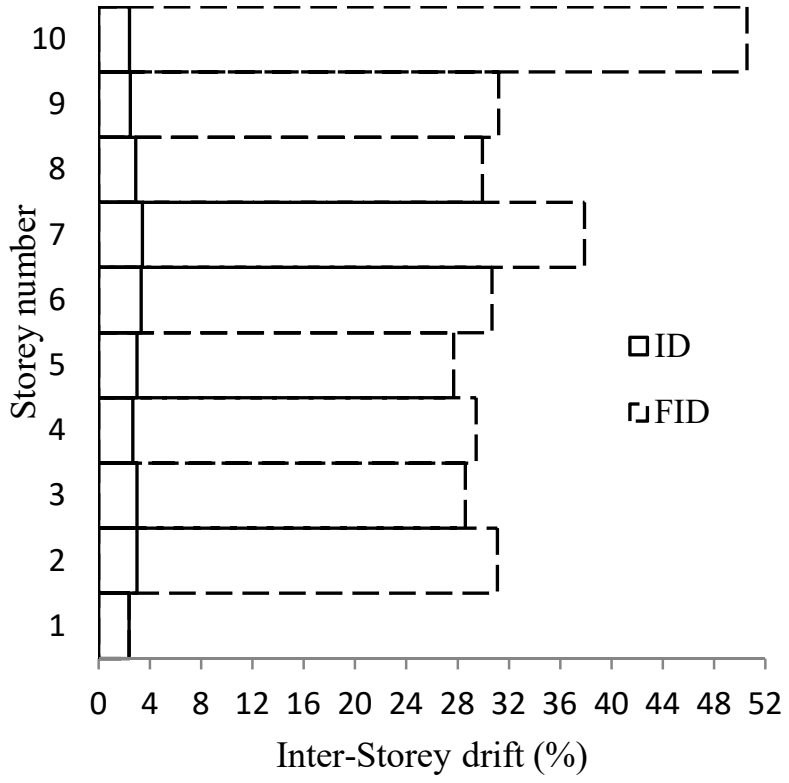

(b)

Figure 18: Results of Frame 10 considering horizontal component of San Fernando Earthquake at Sa(T1) $=0.339 \mathrm{~g}$ (a) Distribution of yielding (b) ID compared with FID limits.

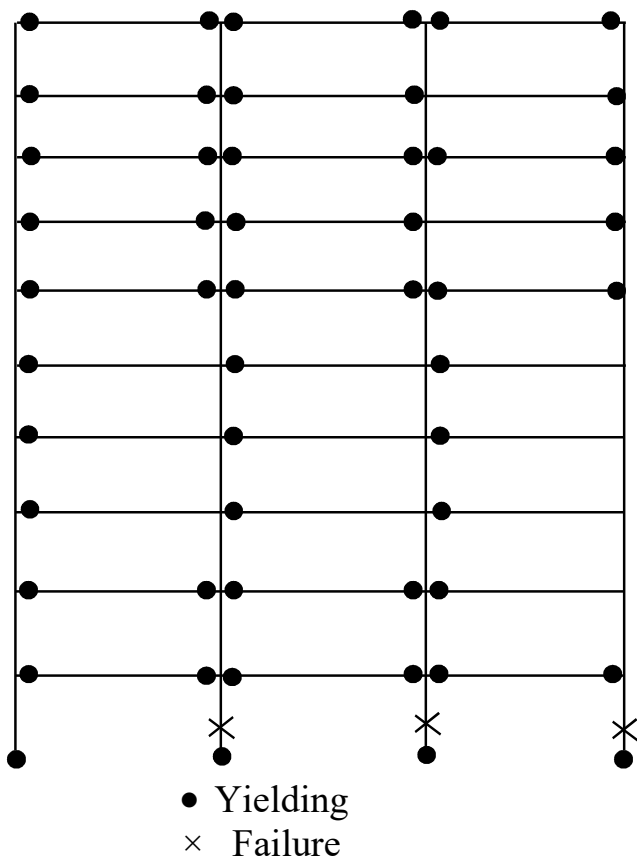

(a)

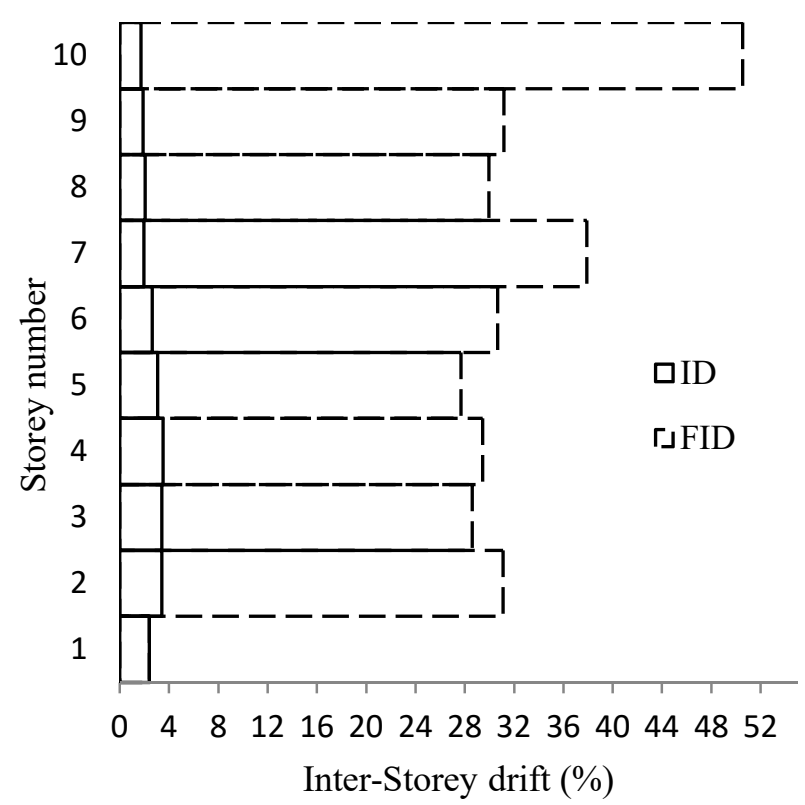

(b)

Figure 19: Results of Frame 10 considering horizontal component of Tabas earthquake at $\mathrm{Sa}(\mathrm{T} 1)=$ $0.351 \mathrm{~g}$ (a) Distribution of yielding (b) ID compared with FID limits. 


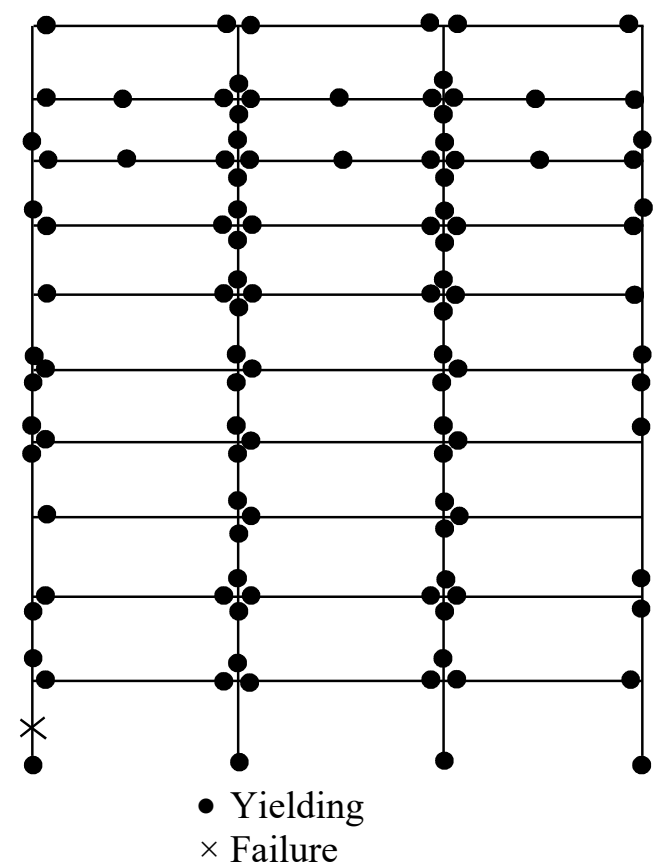

(a)

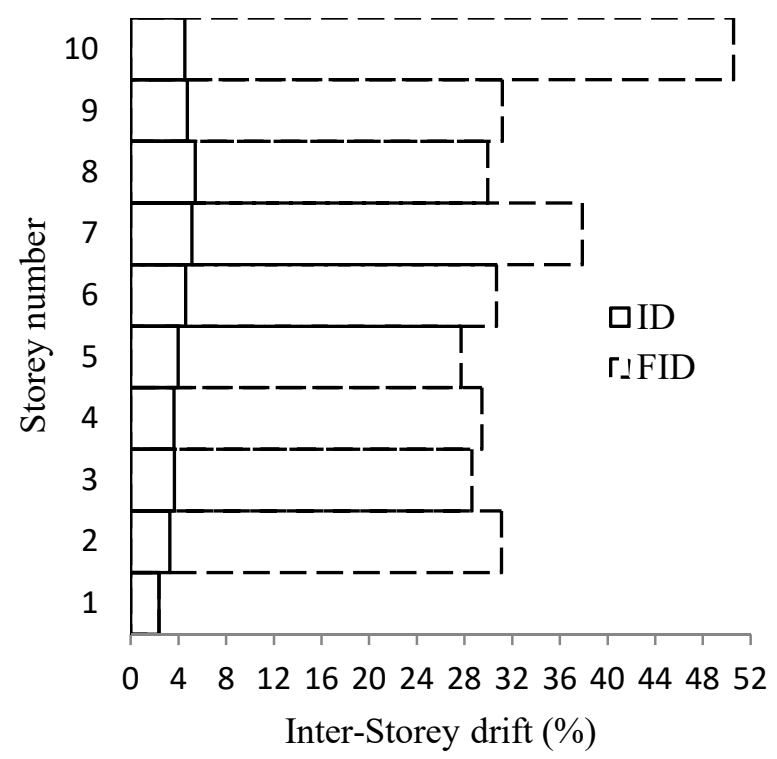

(b)

Figure 20: Results of Frame 10 considering horizontal component of Loma earthquake at Sa (T1) = $0.573 \mathrm{~g}$ (a) Distribution of yielding (b) ID compared with FID limits.

\subsection{Inter-storey drift limit at yield}

As the first storey was the severely damaged storey for all of the considered frames, further validation of the proposed method was conducted considering Frame 10. For this purpose, the storey specific ID limits at yield (YID) were calculated as shown in Figure 21.

For all five ground motions, the ID of the $1^{\text {st }}$ storey exceeded the YID which explained the yielding of all the columns of that storey (Figures 16 to 20). Northridge and Loma earthquakes were considered to further explain the yield distribution of Frame 10.

Due to Northridge earthquake, interior columns of the $2^{\text {nd }}, 4^{\text {th }}, 5^{\text {th }}, 6^{\text {th }}$ and $8^{\text {th }}$ storey yielded (Figure 17). The YID limits for these storeys were close to the experienced ID as shown in Figure 21(a). Although columns of the $3^{\text {rd }}$ and $9^{\text {th }}$ storeys did not yield, the strain of the interior columns were 0.00174 and 0.00160 , which were very close to the yield strain $(0.00177)$. 
The ID of the Frame 10 due to Loma earthquake was compared with the YID limits, Figure 21(b). It was observed that the ID values exceed the YID limits for the $1^{\text {st }}, 5^{\text {th }}, 6^{\text {th }}, 8^{\text {th }}$ and $9^{\text {th }}$ storeys, which explained the yielding of all columns at these storeys, Figure 20. The ID of the $7^{\text {th }}$ storey was almost equal to the YID limit reflecting yielding of the interior columns. The strains of the exterior columns of this storey reached 0.0016 , which was close to the yield strain (0.00177).

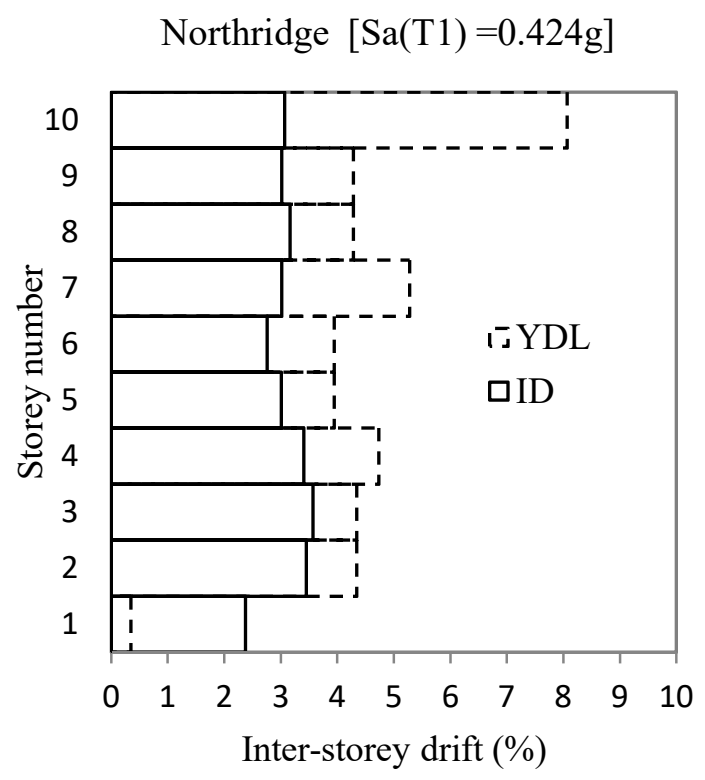

(a)
Loma earthquake $[\mathrm{Sa}(\mathrm{T} 1)=0.573 \mathrm{~g}]$

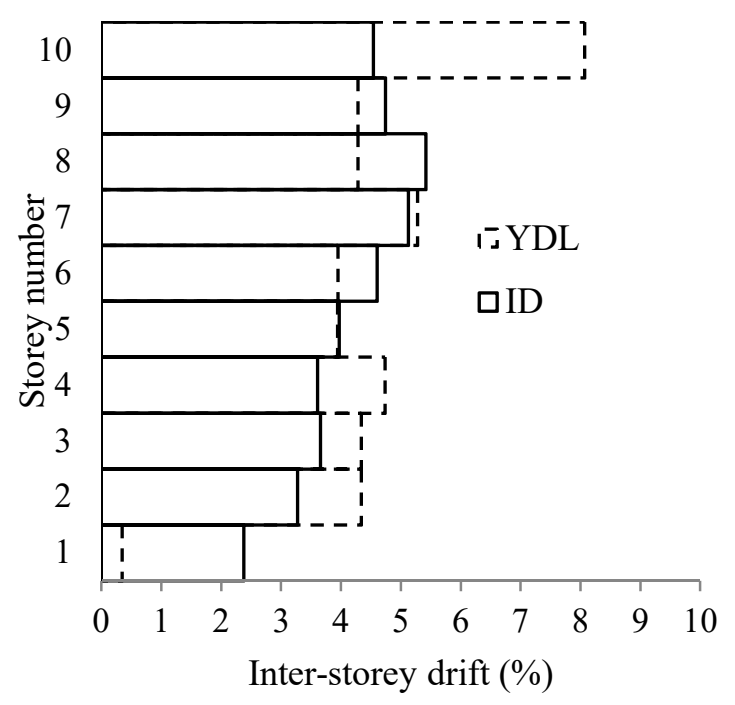

(b)

Figure 21: Comparison of YDL and ID for horizontal component of Northridge $[\mathrm{Sa}(\mathrm{T} 1)=0.424 \mathrm{~g}]$ and Loma Earthquake $[\mathrm{Sa}(\mathrm{T} 1)=0.573 \mathrm{~g}$ ]

\subsection{Building damage considering the seismic vertical components}

The FID limits were modified to account for the effect of vertical component of the ground motions. For the analyzed frames, the extra vertical loads reduced the ductility of the columns. Figure 22 shows the FIDs considering only the horizontal component and both the horizontal and vertical components. The effect of vertical component on the FID was not significant for Frame 3. For Frame 10, the assumed extra vertical forces resulted in up to $58 \%$ reduction in the FIDs. 


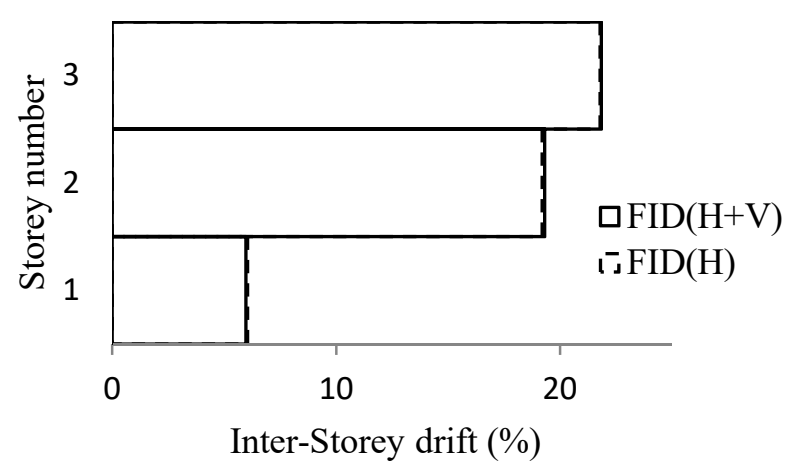

(a) Frame 3

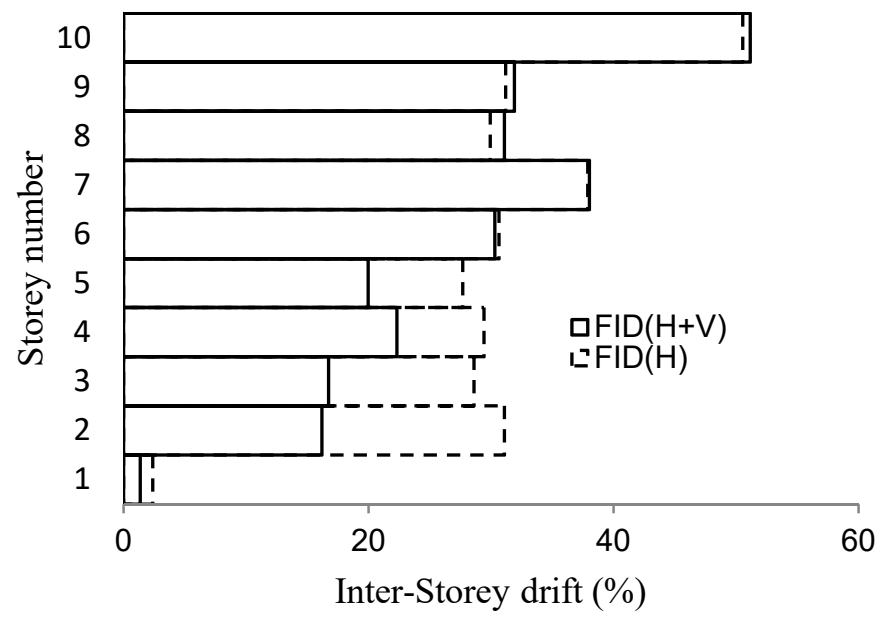

(b) Frame 10

Figure 22: Proposed Limiting FID considering horizontal and both horizontal and vertical components of ground motion.

Figures 23 to 32 show the results of the dynamic analysis considering both the horizontal and vertical seismic components. For Frame 3, the ends and mid-spans of all beams yielded. Three columns of the $1^{\text {st }}$ floor failed due to Loma, Northridge and San Fernando earthquakes and two columns failed in the case of Imperial earthquake as shown in Figures 23(a), 24(a), 25(a) and 26(a), respectively. The ID of the floor was equal to the predicted FID, which indicated that the first floor was the severely damaged floor. Considering Tabas earthquake, the first floor column yielded, however none of the columns failed, Figure 27(a). Thus, the proposed method was found to be conservative for Tabas earthquake due to the overestimation of the extra vertical loads that accounted for the effect of the vertical component.

Figures 28 to 32 show the results of the dynamic analysis of Frame 10 considering the horizontal and vertical seismic components. All of the first floor columns and the interior columns of the $2^{\text {nd }}$ to $6^{\text {th }}$ floors yielded due to Loma earthquake as shown in the Figure 28(a). 
Two interior columns of the $1^{\text {st }}$ floor failed. For Imperial, Northridge, and Tabas earthquakes, all four columns of the $1^{\text {st }}$ floor yielded (Figures 29 to 31 ). For San Fernando, the $1^{\text {st }}$ storey columns and the interior columns of the $2^{\text {nd }}$ storey yielded (Figure 32). However, none of the columns failed. The proposed FID limits were found to be either accurate or conservative.

\subsection{Deflection of beams}

The results obtained from the dynamic analysis considering the vertical component of the seismic motions showed that the vertical component caused the beams to have high vertical deflections. The mid-span deflections expressed as a ratio to the beam span were $3.12 \%$ for frame 3 at its top floor due to Imperial earthquake, and 1.28\% for Frame 10 at its ninth storey due to Loma earthquake.

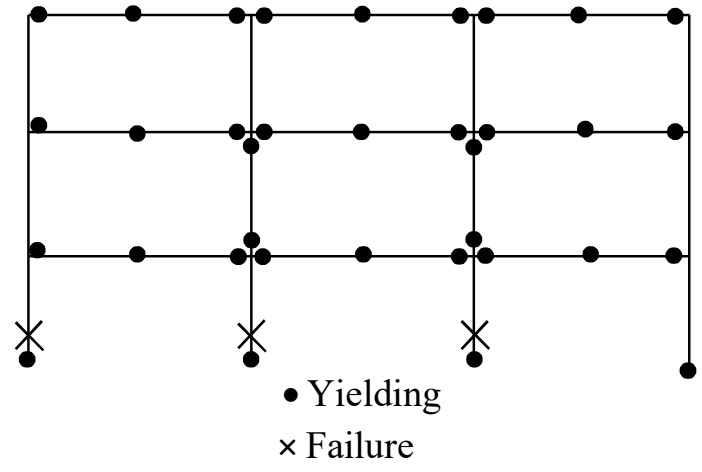

(a)

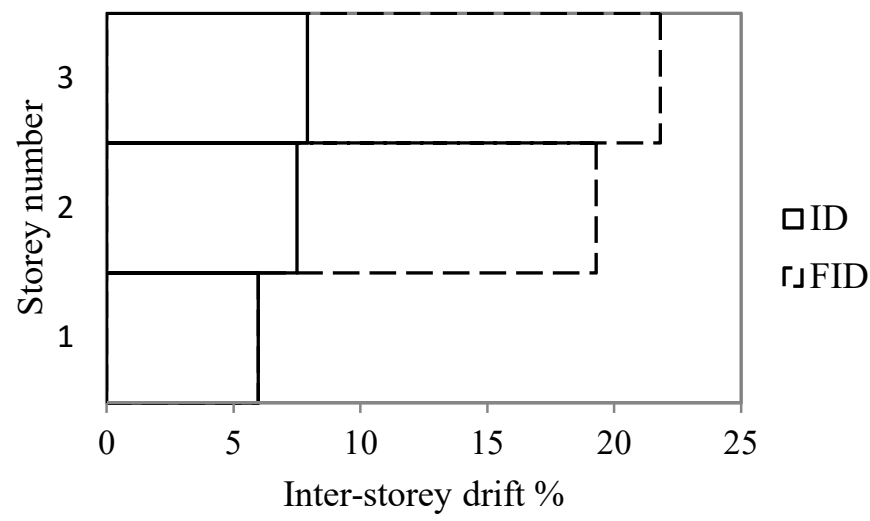

(b)

Figure 23: Results of Frame 3 considering horizontal and vertical component of Loma earthquake at $\mathrm{Sa}(\mathrm{T} 1)=31.87 \mathrm{~g}$ (a) Yielding distribution (b) ID compared with FID 


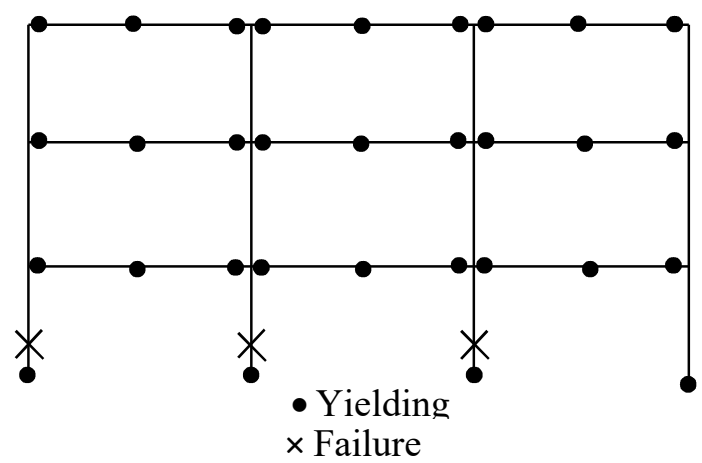

(a)

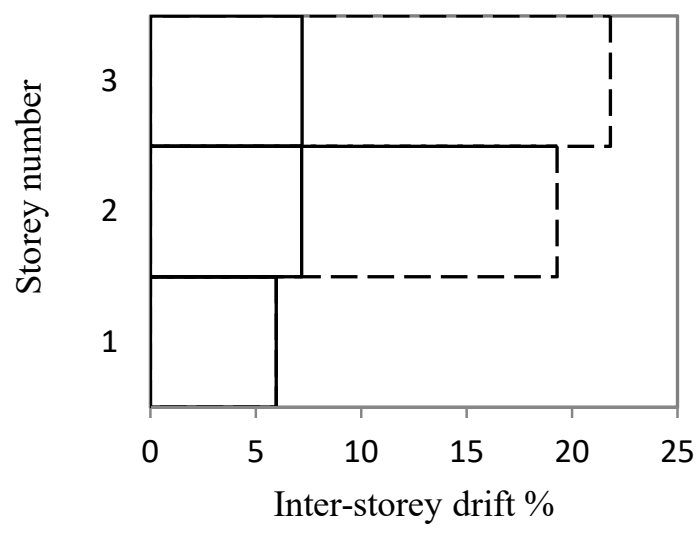

(b)

Figure 24: Results of Frame 3 considering horizontal and vertical component of Northridge earthquake at $\mathrm{Sa}(\mathrm{T} 1)=13.67 \mathrm{~g}$ (a) Yielding distribution (b) ID compared with FID

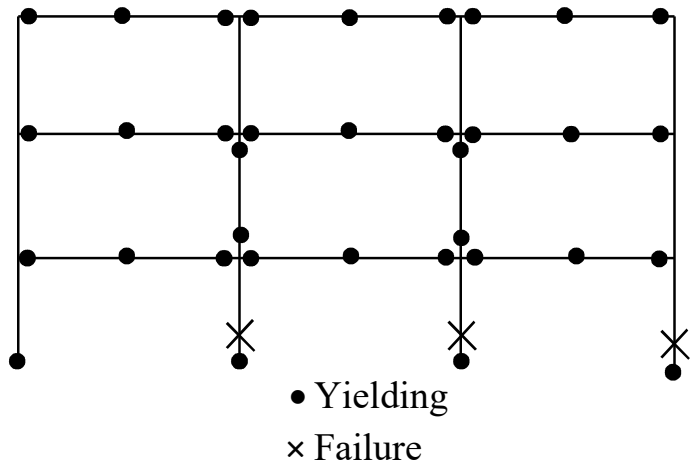

(a)

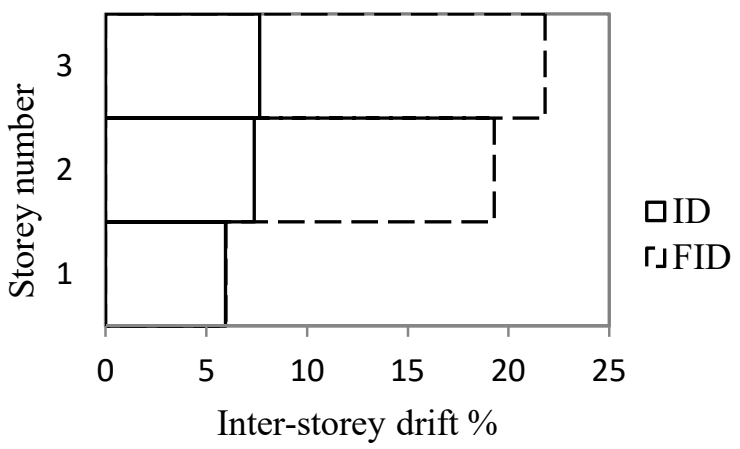

(b)

Figure 25: Results of Frame 3 considering horizontal and vertical component of San Fernando earthquake at $\mathrm{Sa}(\mathrm{T} 1)=17.25 \mathrm{~g}$ (a) Yielding distribution (b) ID compared with FID

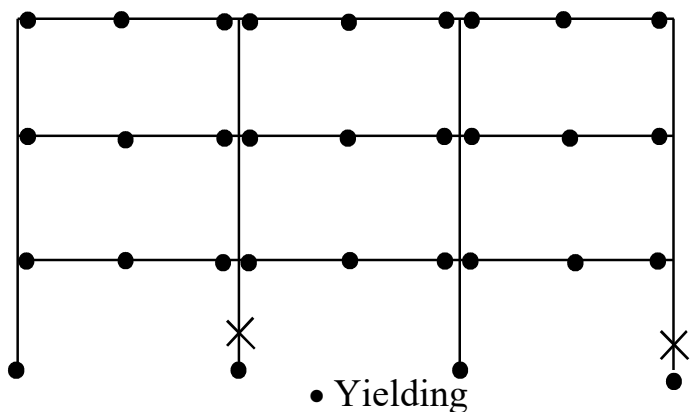

$\times$ Failure

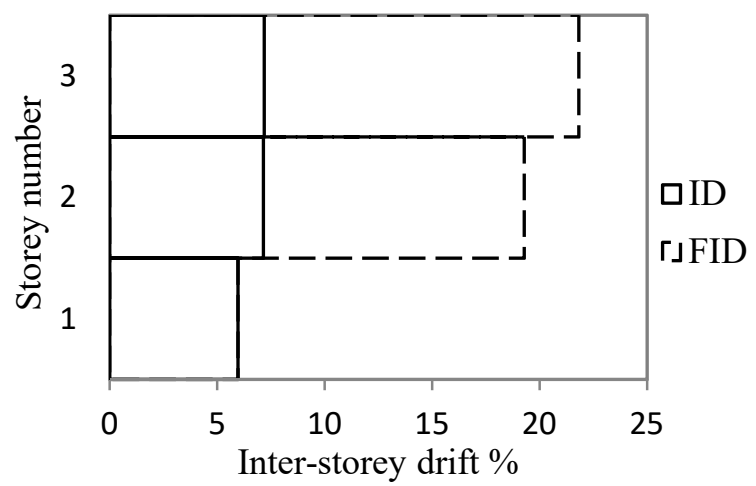

(a)

(b)

Figure 26: Results of Frame 3 considering horizontal and vertical component of Imperial earthquake at $\mathrm{Sa}(\mathrm{T} 1)=10.14 \mathrm{~g}$ (a) Yielding distribution (b) ID compared with FID. 


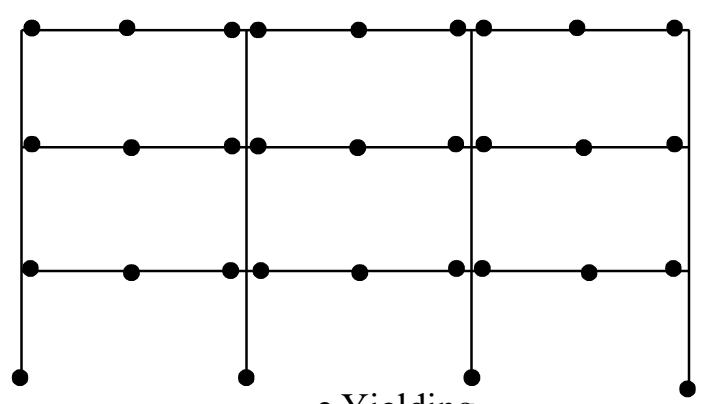

- Yielding

$\times$ Failure

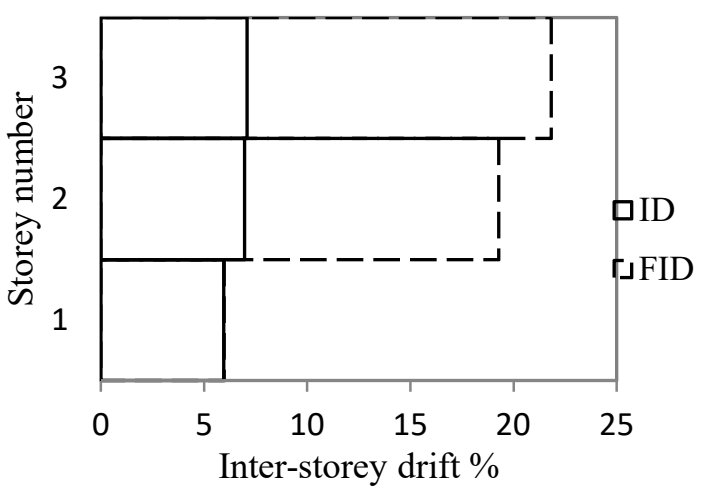

(b)

Figure 27: Results of Frame 3 considering horizontal and vertical component of Tabas earthquake at $\mathrm{Sa}(\mathrm{T} 1)=15.07 \mathrm{~g}$ (a) Yielding distribution (b) ID compared with FID.

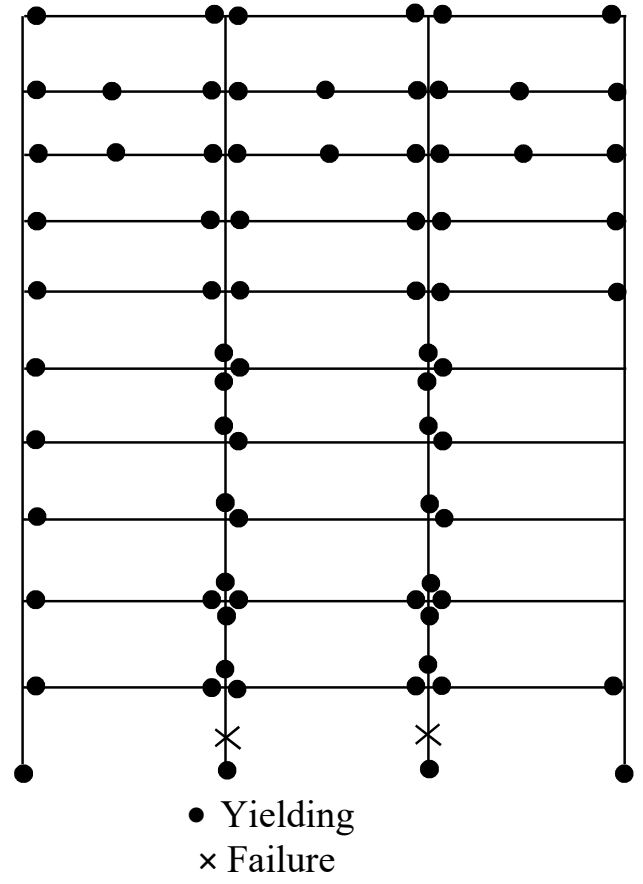

(a)

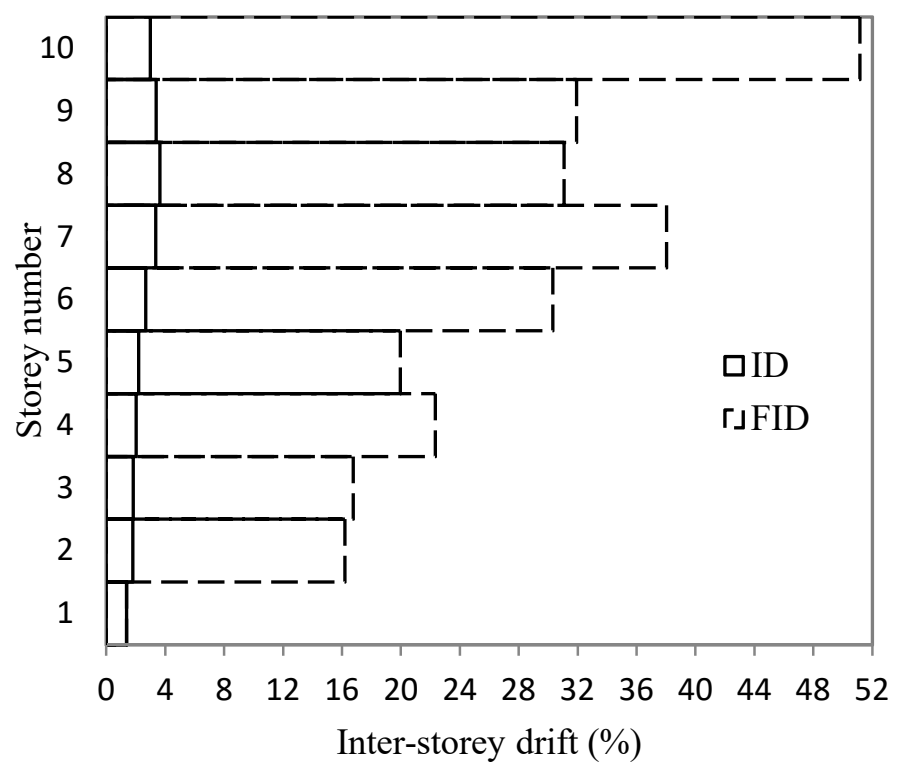

(b)

Figure 28: Results of Frame 10 considering horizontal and vertical component of Loma earthquake at $\mathrm{Sa}(\mathrm{T} 1)=0.325 \mathrm{~g}$ (a) Yielding distribution (b) ID compared with FID. 


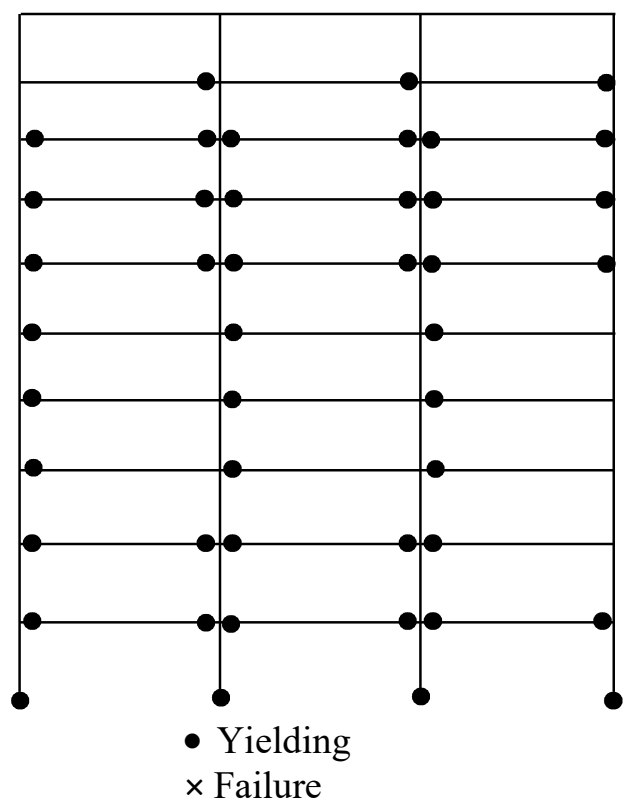

(a)

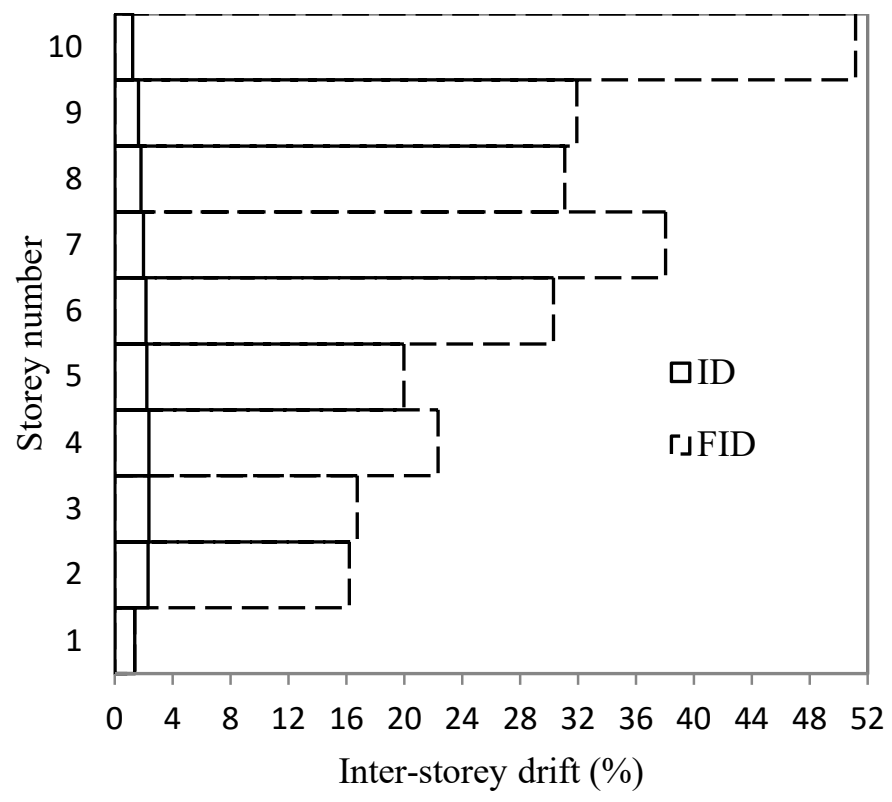

(b)

Figure 29: Results of Frame 10 considering horizontal and vertical component of Imperial earthquake at $\mathrm{Sa}(\mathrm{T} 1)=0.271 \mathrm{~g}$ (a) Distribution of yielding ( (b) ID compared with FID limit.

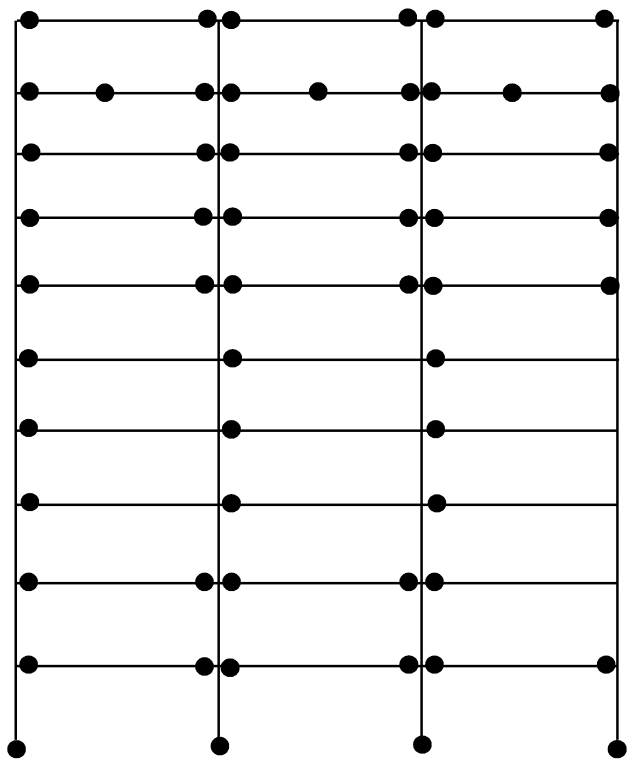

- Yielding

$\times$ Failure

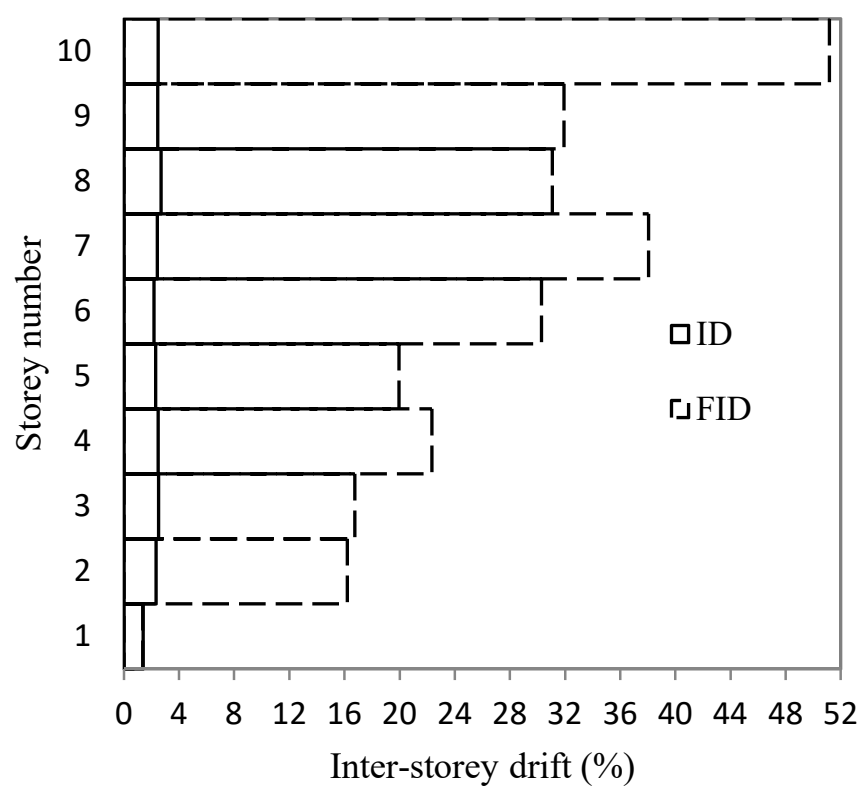

(b)

Figure 30: Results of Frame 10 considering horizontal and vertical component of Northridge earthquake at $\mathrm{Sa}(\mathrm{T} 1)=0.313 \mathrm{~g}$ (a) Distribution of yielding ( (b) ID compared with FID limit. 


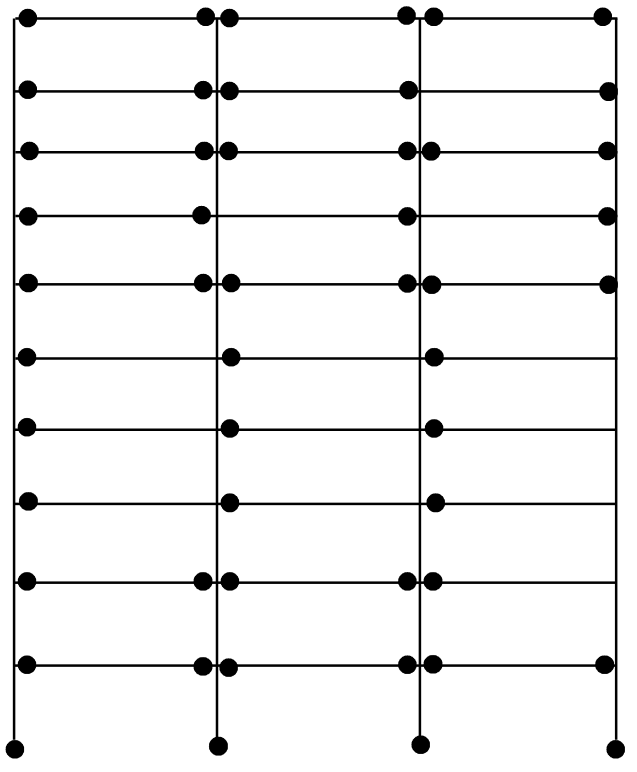

- Yielding

$\times$ Failure

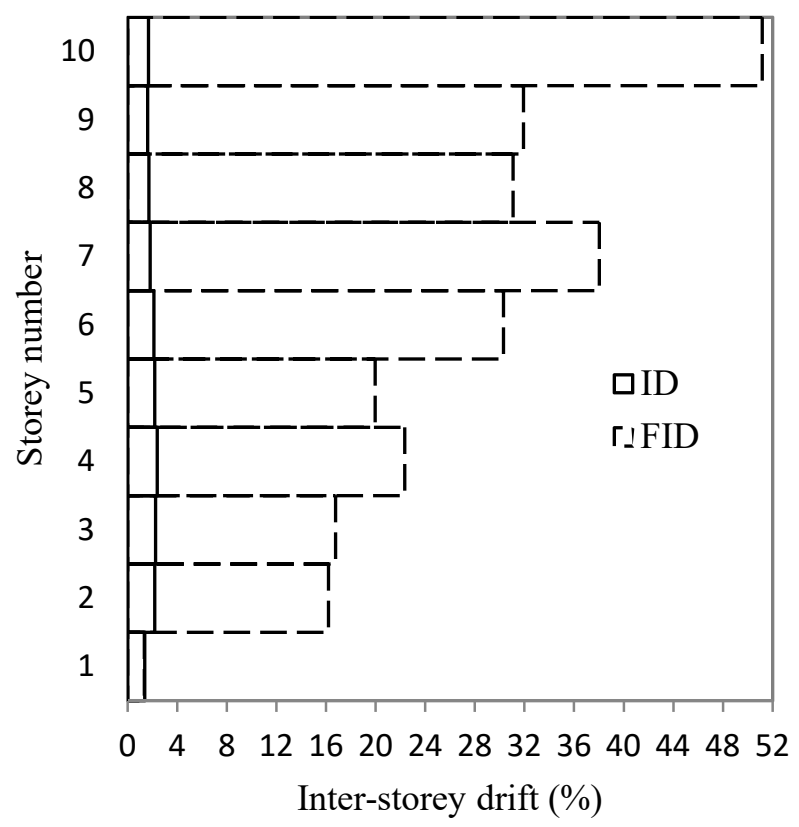

(b)

Figure 31: Results of Frame 10 considering horizontal and vertical component of Tabas earthquake at $\mathrm{Sa}(\mathrm{T} 1)=0.27 \mathrm{~g}$ (a) Distribution of yielding ( (b) ID compared with FID limit.

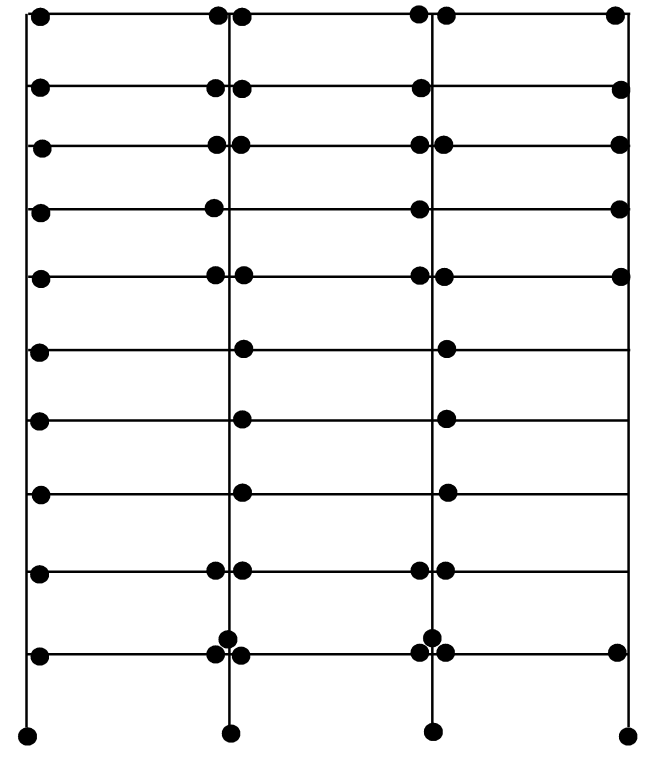

- Yielding

$\times$ Failure

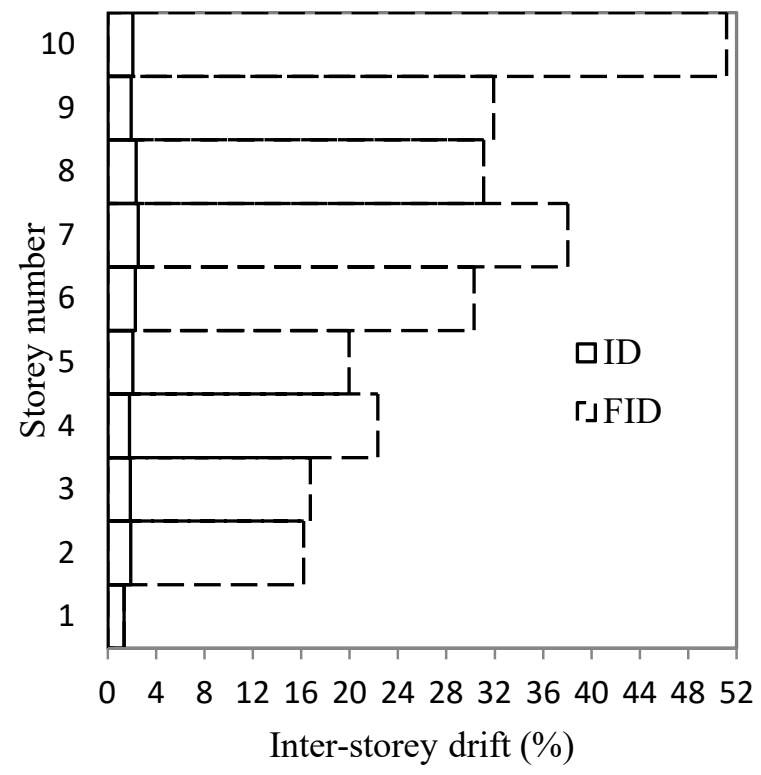

(a)

(b)

Figure 32: Results of Frame 10 considering horizontal and vertical component of San Fernando earthquake at $\mathrm{Sa}(\mathrm{T} 1)=0.244 \mathrm{~g}$ (a) Distribution of yielding ( (b) ID compared with FID limit. 


\subsection{SUMMARY AND CONCLUSIONS}

Local damage of SMRFs cannot be identified using a single value of ID because the storey experiencing the MID is not necessary the severely damaged storey. A simplified method, which is based on pushover analysis, is proposed to calculate the failure inter-storey drifts (FIDs) of SMRFs corresponding to each storey. The method takes into account the rotation of the lower stories, P- $\Delta$ effect and the vertical seismic component. The effect of vertical seismic component on the FID limit is incorporated by adding extra vertical loads that can be estimated by multiplying the mass of each floor by the vertical design spectral acceleration. The proposed method was validated using experimental and analytical studies by other researchers. A threestorey and ten-storey SMRFs were considered as case studies to further validate the method. The FIDs were calculated according to the proposed method while considering or ignoring the effect

of the vertical seismic component. Both static and nonlinear dynamic analyses were performed considering five different ground motions. The static and dynamic analyses showed that the predicted limits accurately identified the critical stories of the frames. The proposed method needs to be extended to account for the three-dimensional behaviour of steel buildings.

\section{ACKNOWLEDGMENT}

The research presented in this paper was funded by the Natural Sciences and Engineering Research Council of Canada (NSERC) and the Ontario Ministry of Training, Colleges and Universities. 


\subsection{REFERENCES}

[1] FEMA 356, Prestandard and commentary for the seismic rehabilitation of buildings, Federal Emergency Management Agency, 2000.

[2] FEMA 350, Recommended seismic design criteria for new steel moment-frame buildings. Federal Emergency Management Agency, 2000.

[3] NZS 1170-5, Structural Design Actions Part 5: Earthquake actions - New Zealand. 2004.

[4] UBC 1997, Uniform Building Code. International Code Council, 1997.

[5] B. Asgarian, A. Norouzi, P. Alanjari, M. Mirtaheri, Evaluation of seismic performance of moment resisting frames considering vertical component of ground motion, Adv. Struct. Eng. 15(8) (2012) 1439-1453.

[6] G.A. Macrae, D. Fields, J. Mattheis, Ground motion characteristic effects on multistory steel frame response, Proc. $12^{\text {th }}$ World Conference on Earthquake Engineering, Auckland, New Zealand, 2000, paper no 1056.

[7] M.S.R. Labafzadeh, M. Tehranizadeh, Non-linear dynamic behavior of structures due to horizontal near field ground motions. Proc. $8^{\text {th }}$ U.S. National Conference on Earthquake Engineering, San Francisco, California, USA, April 18-22, 2006, paper No. 714

[8] K.H. Abdelkareem, A. Machida, Effects of vertical motion of failure mode and ductility of RC bridge piers, Proc. $12^{\text {th }}$ World Conference on Earthquake Engineering, Auckland, New Zealand, 2000, paper no. 0463.

[9] Eurocode 8. Design of structures for earthquake resistance, Part 1: General rules, seismic actions, and rules for buildings, European Committee for Standardization (CEN), 2004.

[10] National Earthquake Hazards Reduction Program (NEHRP), Recommended seismic provisions for new buildings and other structures: Part 1, Washington D.C., 2009.

[11] M.A. Youssef, M.A. Elfeki, Predicting local seismic damage of RC framed buildings considering the horizontal seismic component, Mag. Concr. Res. 65(23) (2013) 1411-1428.

[12] K. Muto, A seismic design analysis of buildings. Maruzen Company Ltd, Tokyo, Japan, 1974.

[13] T. Paulay, M.J.N. Priestley, Seismic design of reinforced concrete and masonry buildings, John Wiley \& Sons, USA, 1992.

[14] M.A. Elfeki, Seismic performance of steel and shape memory alloy reinforced concrete framed buildings, PhD thesis, Western University, London, Ontario, Canada, 2009.

[15] SeismoStruct (version 6) - A computer program for static and dynamic nonlinear analysis of framed structures, available online from $h t t p: / / w w w . s e i s m o s o f t . c o m$

[16] J. Wan Hu, Smart connection systems: design and seismic analysis, Taylor \& Francis, 2015.

[17] K. Suita, S. Yamada, M. Tada, K. Kasai, Y. Matsuoka, Y. Shimada, Collapse experiment on 4story steel moment frame Part 2 detail of collapse behavior, $14^{\text {th }}$ World Conference on Earthquake Engineering, Beijing, China; October 12-17, 2008.

[18] J.F. Hajjar, C.B Gourley, D.P. O'Sullivan, R.T. Leon, Analysis of mid-rise steel frame damaged in Northridge earthquake, J. Perform. Constr. Facil. 12 (4) (1998) 221-231.

[19] S.E. Kim, D.H. Lee, C. Ngo-Huu, Shaking table tests of a two story unbraced steel frame, J. Constr. Steel Res. 63 (2007) 412-421.

[20] A. Gupta, H. Krawinkler, Seismic demands for performance evaluation of steel moment resisting frame structures, John A. Blume Earthquake Engineering Center, Department of Civil Engineering, Stanford University, USA, 1999, report No. 132.

[21] D. Ozhendekci, N. Ozhendekci, Seismic performance of steel special moment resisting frames with different span arrangements. J. Constr. Steel Res. 72 (2012) 51-60.

[22] PEER ground motion database, Pacific earthquake engineering research center, University of California, Berkeley, USA, 2013, http://ngawest2.berkeley.edu/. 


\section{List of notations}

$b_{f}$
$d_{c t}$
$E_{s}$
$F_{y e}$
$h$
$h_{c}$
$I_{b}$
$I_{c}$
$K_{b}$
$K_{c}$
$K_{t}$
$K_{1} K_{2} K_{3} \& K_{4}$
$L$
$m$
$m_{a v}$
$M_{c b}$
$M_{c t}$
$P$
$P_{C L}$
$t_{f}$
$t_{w}$
$V_{f}$
$V_{i}$
$\alpha$
$\Delta_{m}$
$\theta_{y}$

Flange width

Moment distribution factor

Modulus of elasticity

Expected yield strength of material

Web height

Column height

Beam moment of inertia

Column moment of inertia

Factor for moment at bottom of column

Stiffness of column

Factor for moment at top of column

Stiffness of beam

Beam span

Drift magnification factor

Average drift magnification factor

Moment acting at bottom of column

Moment acting at top of column

Axial force

Lower bound compression strength of column

Flange thickness

Web thickness

Shear force for fully restrained column

Shear force for partially restrained column

Reduction factor for lateral stiffness

Inter-storey drift

Yield rotation 